Historic, archived docum

Do not assume content reflects cur scientific knowledge, policies, or pra 

62.73
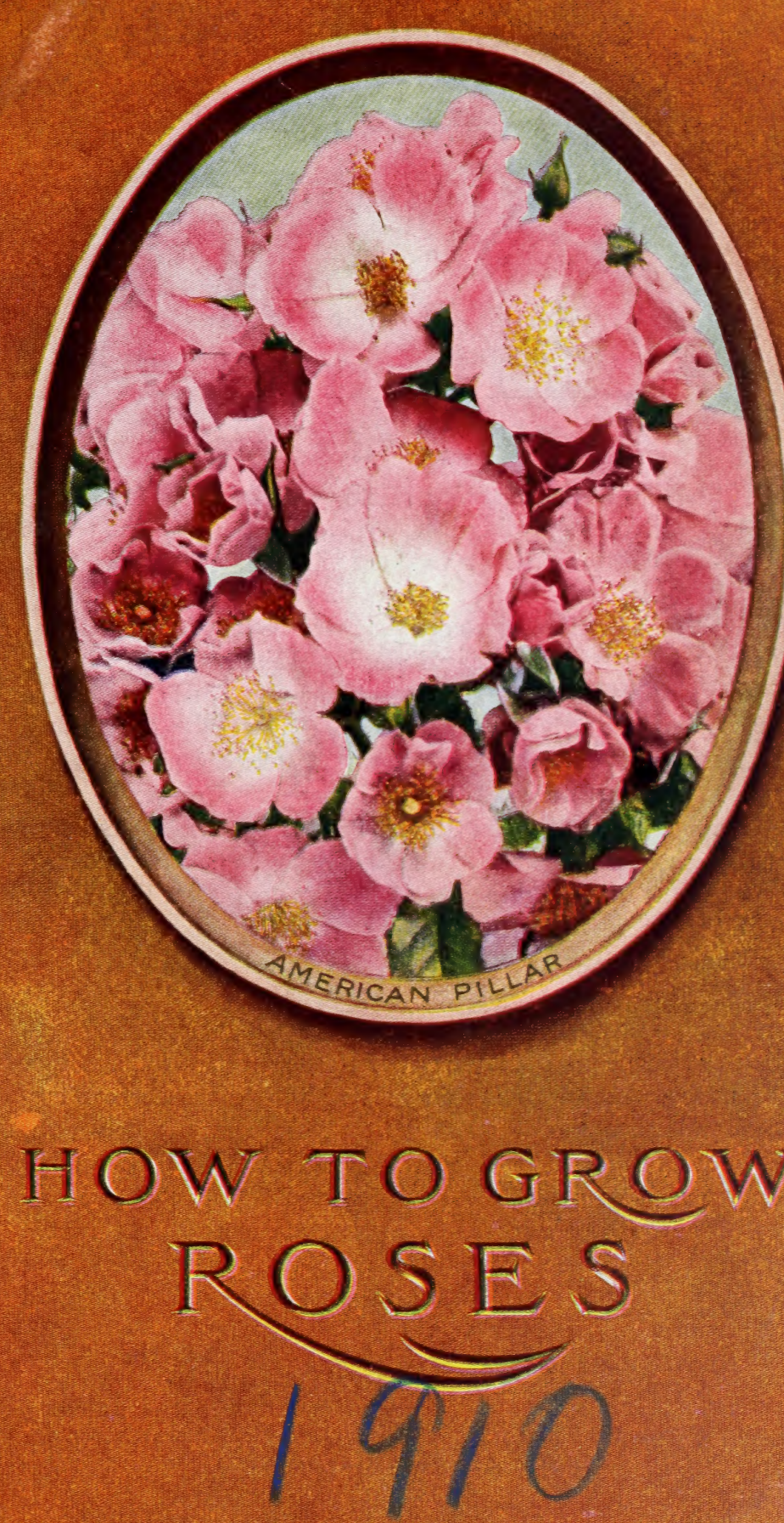

THE CONARD \& JONES CO. WEST GROVE, PA. 


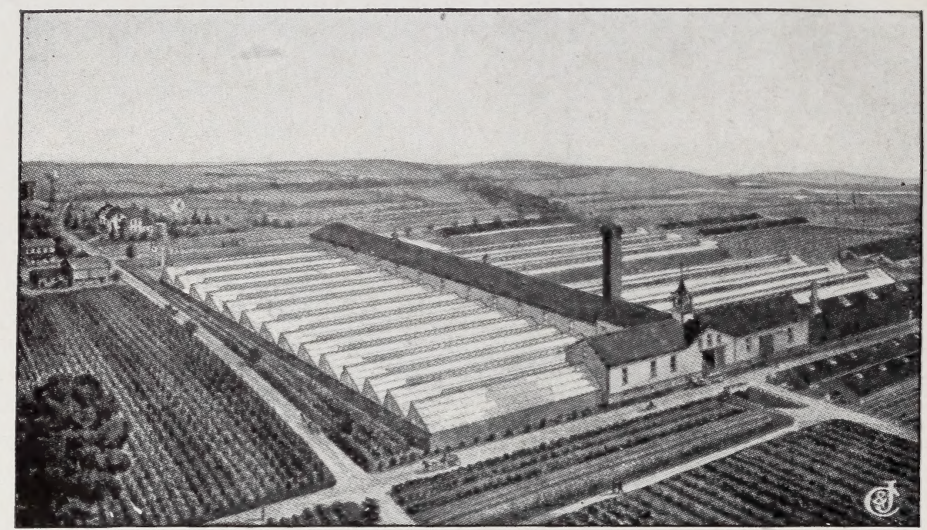

We invite visitors to see our great rose-growing plant

\section{A Word About Ourselves}

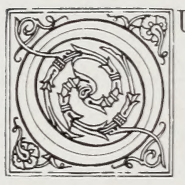

UR business story starts with the beginning of the Rose-growing industry in America. It was in West Grove, a little past the middle of the last century, that Alfred F. Conard, the founder of our firm, took the first steps as leader in the small beginning of the new industry of growing Roses on their own roots. It was he who placed the first advertisement, and wrote and compiled the first catalogue offering Roses by mail.

Associated with him as grower was our vice-president and superintendent of today, Antoine Wintzer-an Alsatian by birth - then but a young man. It has been Mr. Wintzer who, with great-hearted love for his task, has personally directed the "making" of most of the Roses which have gone out from West Grove since that time to thousands upon thousands of happy homes in nearly every country on earth.

A lifetime is short to learn what there is to be known about preparing Roses fit for America's millions. We do not boast of the past, but we do know that our experience is priceless, and that the methods thus learned now help us to produce for our customers what we believe to be the best Roses that can be grown.

With an extensive block of new greenhouses, provided with all the modern improvements for heating, ventilating, etc., and with a skilled corps of young men trained under our methods, with the grand original rose-maker still "on the job," we are surely well prepared to handle any kind of a Rose order that this good round world may send our way.

\section{THE CONARD \& JONES CO.}

Robert Pyle, President Antoine Wintzer, Vice-President

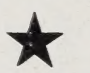

R. T. Satterthwaite, Secretary

S. Morris Jones, Treasurer

For price of cover-page Roses, see page 35 


\section{3⿻ow to Grow Riosics}

BEING A TRUSTY GUIDE TO SUCCESSFUL ROSE-GROWING-DIVIDED INTO FIVE SECTIONS, AS FOLLOWS :

\section{How to Go About It PAGES 5-8}

II. How to Have a Harvest of Bloom PAGES 8-12

III. All You Need to Know About Each of 101 Roses PAGES 13-24

IV. Getting Right Roses for Any Place and Purpose PAGES 25-33

V. The Rose-Lover's Calendar PAGE 34

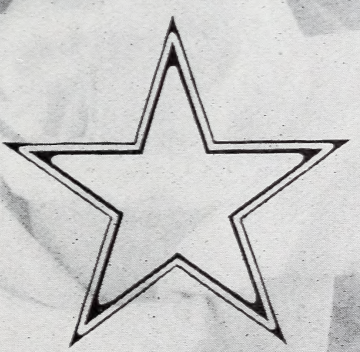

PUBLISHED AND COPYRIGHTED; 1910, BY

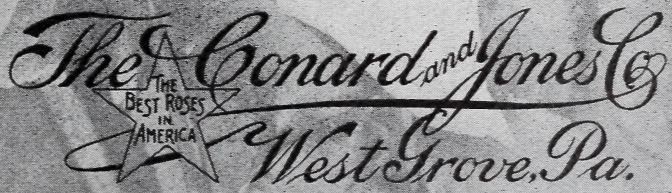




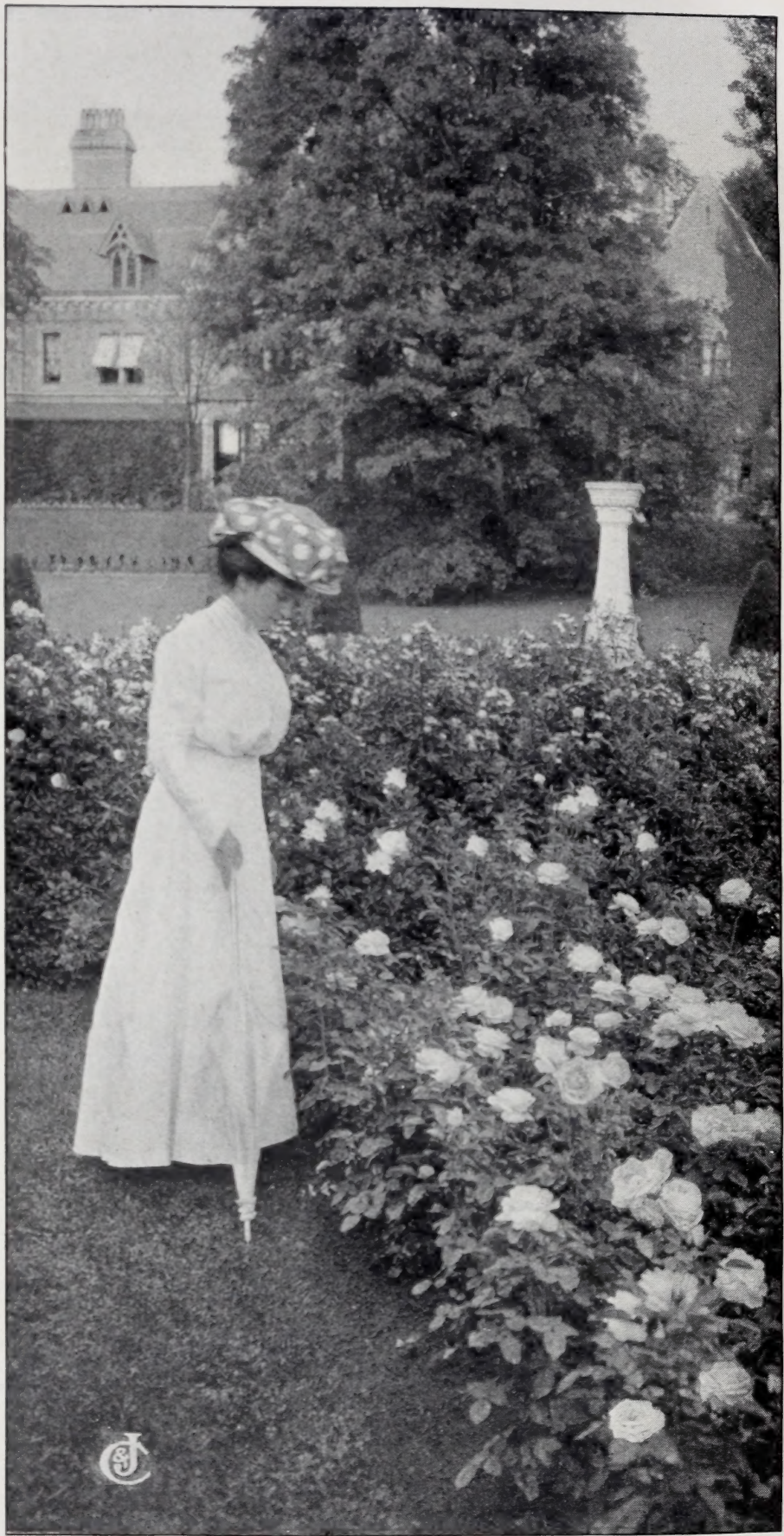

“ Just a little garden of these modern well-bred Roses; just a little daily, loving care; just a little cost, and the result to you and your neighbors is the glory of the Queen of Flowers." (See page 5.) 


\section{The 20sest Hroses in America is}
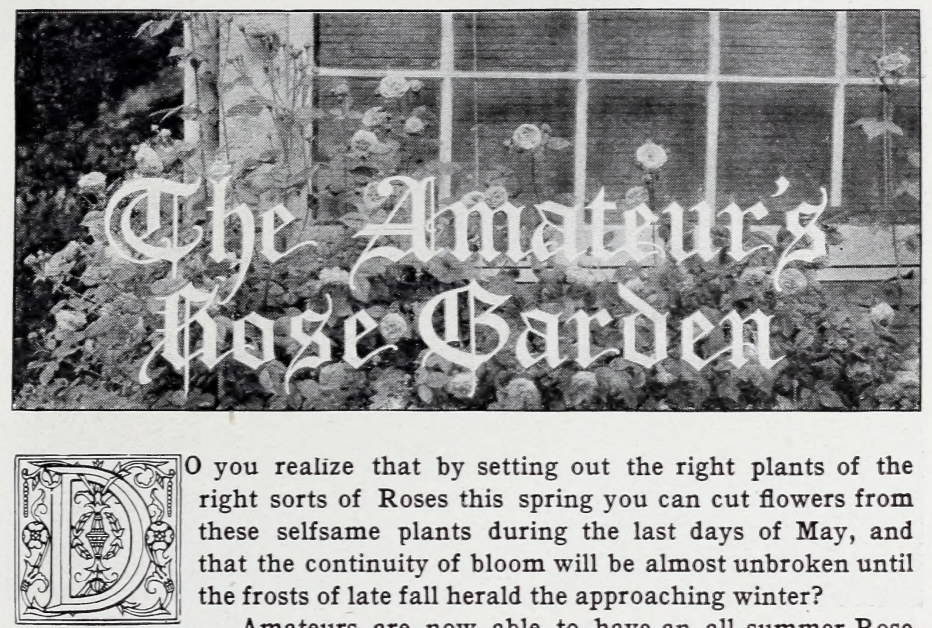

0 you realize that by setting out the right plants of the right sorts of Roses this spring you can cut flowers from these selfsame plants during the last days of May, and that the continuity of bloom will be almost unbroken until the frosts of late fall herald the approaching winter?

Amateurs are now able to have an all-summer Rose feast as well as the most skilled professional, and it is in the amateur's Rose-garden, too, that these fragrant blossoms may be gathered with early icicles hanging to them.

Nor is a large garden requisite - two or three dozen good plants, of the modern and greatly improved sorts, properly selected, will give much enjoyment, while a garden of Roses can be readily made a summerlong delight.

In the spring one can have the fun of building air-castles about the plants. When the warm days of June arrive, these air-castles have taken substantial form, and you go from one plant to another, giving each a little daily attention, contrasting one proud beauty with another equally queenly, and, best of all, gathering an abundance of lovely Roses. IIalf an hour of such tonic toil each day is a great nerve-restorer, and, what is more, it is the best food for the soul.

Rose-growing among amateurs in this country is yet in its infancy. In England, nearly everybody grows Roses; there are dazzling vistas of Roses in the hedge-rows along the country roads and lanes; there are gardens full, each person striving in friendly rivalry with his neighbor. Why do our friends on the other side of the sea become so enthusiastic over the Rose? Because it is without a peer among all the flowering plants. It presents nearly every floral shade, in combinations far more attractive than exotic orchids, and, above all, it gives to us enjoyment of another sense in its delicious fragrance - the crowning feature, in which no other flower can compete with it.

For centuries has the Rose been fully recognized as the Queen of Flowers, honored alike by poet and king.

Yet such varieties as Frau Karl Druschki, Killarney and Wm. R. Smith, the ancients never knew! Why, then, should not you and yours share in the pleasures of the Twentieth Century Roses, to your own enjoyment and to the advantage of those around you? Just a little garden of these modern well-bred Roses; just a little daily, loving care; just a little cost-and the result to you and your neighbors is the glory of the Queen of Flowers. 


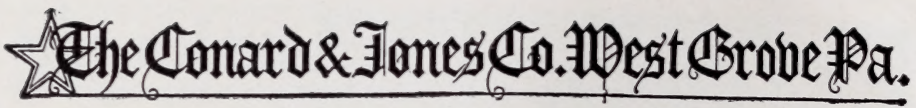

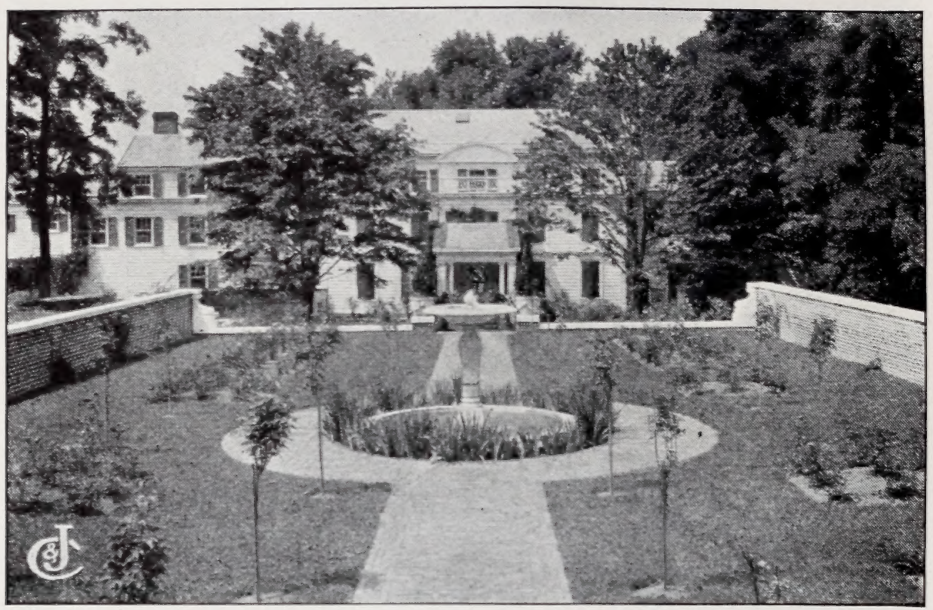

The Formal Garden is incomplete without Roses

(See this one explained below, and for one year later picture see next page)

\section{WHERE TO GROW ROSES}

LOCATING THE BED. Roses may be grown in any place where there is sunlight during most of the day. The kind of soil is immaterial, for it can be made to suit the requirements of the Rose. (See further, page 8.) Your yard will grow Roses if there is sunshine in it for five or six hours a day and a good circulation of air. The average home grounds usually have several available spots for Rose-beds. An eastern exposure is preferable. The presence of trees is not a disadvantage, provided the Roses are not so close that the treeroots rob the bed of its plant-food.

DIMENSIONS. The young garden at the top of this page is well laid out. Note the avenue effect produced by the double row of Standard or Tree Roses on either side of the walk (they should be set at intervals of from 4 to $\mathrm{Io} \mathrm{ft}$.). They remind one of the beautiful Rose-gardens in England. Up the wall on either side, Climbing Roses have been started. The front bed on the left in the picture is $4 \frac{1}{2}$ feet square, and contains 9 Roses. The front bed on the right is $4 \frac{1}{2}$ feet wide by 6 feet long, and contains 12 Roses. The rear bed on the right of the walk is $4 \frac{1}{2}$ feet wide by I 3 feet long, and con-

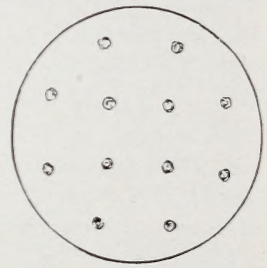

Six feet diameter for twelve Roses tains 24 Roses; and the long bed in the rear on the left is $4 \frac{1}{2}$ feet wide by 20 feet long, and contains 36 Roses.

Beds $4 \frac{1}{2}$ feet wide accommodate three rows nicely (as above), I 2 Roses to every 6 feet. The diagram below shows a bed 3 feet wide for two rows, and will require I 2 Roses to every 9 feet; 24 Roses if 18 feet long, etc. The above estimate is based upon planting the Roses 18 inches apart each way. Eighteen inches to 2 feet is about the right spacing for most bedding Roses. In warm countries, where growth is most

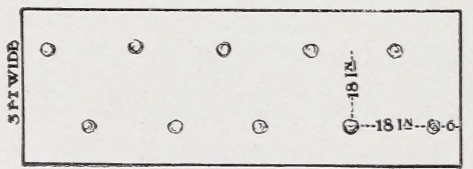

8FT 6 Iㄴ LONG luxuriant, and for the big, bushy sorts, more room will be required.

Beds of any other shape or size may be laid out to suit one's fancy. I 2 Roses in a Round bed 6 feet in diameter. In making large beds and Rose-gardens, provide for a pathway between every three or 


\section{The 20est Groses in America 直}

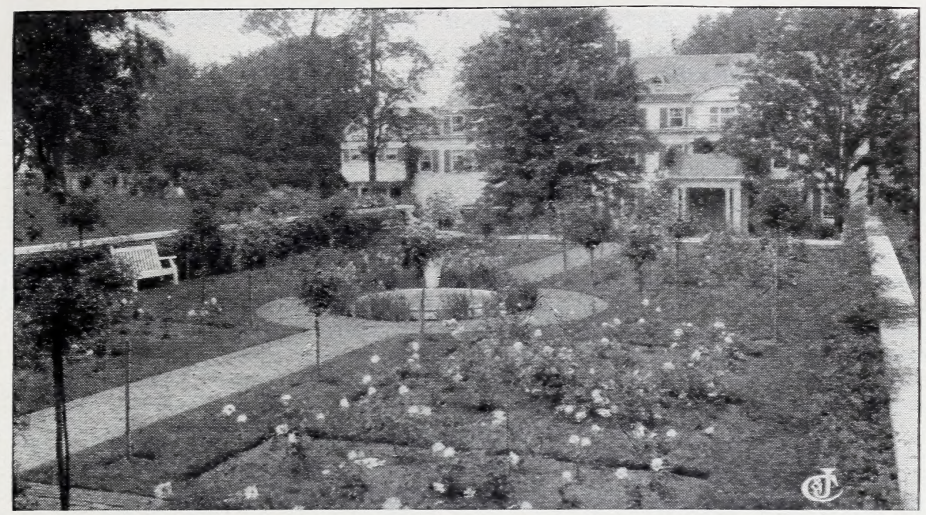

See opposite page and note the growth of one year

four rows, so the Roses can be cut and cultivated without treading on the loose soil.

THE KIND OF ROSES that one buys is of great importance to the purchaser. Our Roses are nearly all grown on their own roots, which we believe are better than budded Roses, except in the case of naturally weak-growing kinds. A Budded Rose is one which has been grafted onto the root of a wild Rose. If the top of budded Roses be winterkilled, the roots left are worthless-not so with the "own-root" Roses, which, if killed back, will grow up again from the root to bloom as fine as ever.

SIZES. We have divided our Roses into three sizes, as follows:

THE ONE-YEAR-OLD ROSES are usually greenhouse-grown, but are well hardened with strong roots and bushy tops, from 6 to I5 inches high, according to variety. This size gives such a harvest of bloom as to more than compensate one for the outlay the first year. (See cut.)

TWO-YEAR-OLD ROSES are the regular large size and should bloom abundantly the first year. Usually they are greenhouse-grown, with specially fibrous roots and well-branched tops from I foot to $2 \frac{1}{2}$ feet high; the size depends upon the variety and habit of growth. Some varieties can be supplied in field-grown, dormant plants until April. (See cut.)

"STAR," or THREE- AND FOUR-YEAR-OLD ROSES. All Roses in this book marked with a star are of this size. These plants are very large, and will produce a big crop of flowers the first year if they are given any attention. The greater show that this class of plants will make the first year will amply repay the slight extra cost. (See cut.)

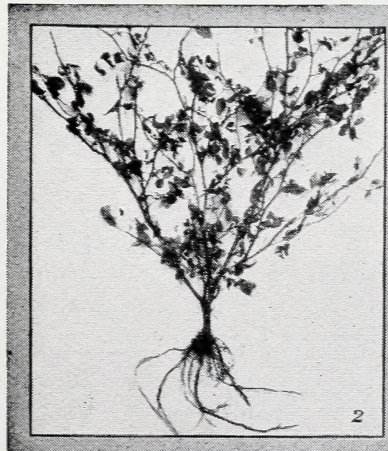

Two-year size

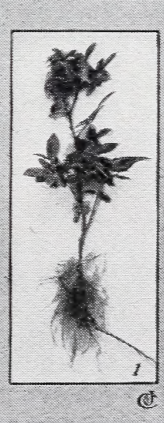

One-year size

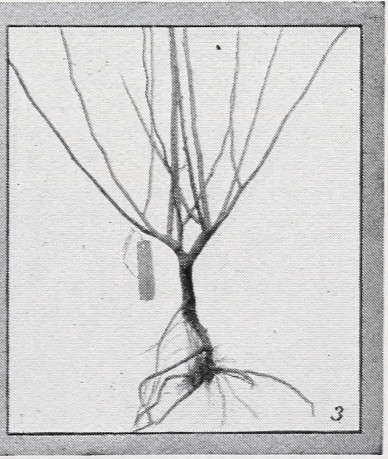

$\star$-size (3-year size, dormant) 
PRICES. Each set is priced where offered and each Rose is priced separately in three sizes (pages I 3 to 24 ). Price per doz. (unless otherwise noted) is ten times the price "each."

IF YOU WISH EXPRESS PREPAID. The one-year size will be sent by mail, postpaid, at prices given. The two-year and $\star$-size must be shipped by express, the purchaser paying express charges upon arrival. But if 5 cents per Rose is added to an order of ten or more plants, we will prepay the charges to destination. We guarantee safe arrival.

SELECTING. To simplify ordering we have reduced the usual list to include only the most desirable kinds and have made up sets of Roses for special localities. So that, in many cases, all that is necessary when ordering is simply to send the money and say which sets you want. While you are waiting for the Roses to arrive, prepare the beds for them (see directions, p. 9, and about shipping, p. 35).

\section{HOW TO GROW ROSES}

A Pleasant Hobby. Growing Roses is not an expensive luxury, neither is not necessary even to does it require a large amount of hard labor. It extent other than SPADING WELL-DECAYED MANURE DEEPLY IN THE SOIL. However, to raise the very best Roses, it is advisable to trench the soil about two and one-half feet deep. When doing this, throw whatever stones may be found in the soil on a pile by themselves, so that they can be put in the bottom of the trench for drainage. There should be four or five inches of this Provide Drainage. drainage material in the bottom of the bed so that Provide Drainage. all surplus water will drain away quickly. If the soil is naturally well drained, it will be unnecessary to provide drainage. Nothing is more prejudicial to the health of Roses than poorly drained soil. Refill the trench with the soil taken from it, to which has been added some well-decayed cow-manure, but do not add manure to the top layer of 9 to 12 inches of soil unless very well decayed, for fresh manure, when it comes in direct contact with Rose roots, injures them. It is a good idea to mix with the soil in the bottom of the trench a few broken bones, say a peck for a bed holding a dozen Rosesthey will furnish plant-food for the Roses for three or four years to come. Tramp the soil in the bed and let it settle. This work should be done as far in advance of planting as possible, so that the soil will be firm at the time of setting the plants. Should the soil be very light or sandy, it can be greatly improved by mixing A LITTLE CLAY WITH IT WHEN TRENCHING. Heavy soils can be made lighter and more open by adding sand, or even coal-ashes.

Time to Plant The best time to plant Roses is in the spring, but hardy Time to Plant. kinds, if they can be had in the dormant state, may be planted in the autumn with success if it is more convenient. If planted in the fall, Roses must be carefully protected. In spring, the Hybrid Perpetuals and the Rugosa Roses should be planted as early as the ground can be worked, which is about the last of March in the latitude of Philadelphia. These can be planted out earlier because they are usually sent in the dormant state, but the Roses which are usually in leaf when shipped should not be planted until late April and on until June. The purchaser should understand that many of our Roses are shipped in full leaf, each plant having a good ball of earth, so that there is no danger of its dying. Some of the Hybrid Perpetuals, the Rugosas, Briars and Hardy Climbers are shipped up to mid-April in dormant condition.

\section{Treatment on Arrival.}

When you receive the Roses, give them the greatest care; never expose the roots to the drying action of spring winds for a moment. A plant with bare roots exposed to the dry air is like a fish out of water. Should the plants, through delay in transit, come dried out, as occasionally happens, soak the balls of earth and roots

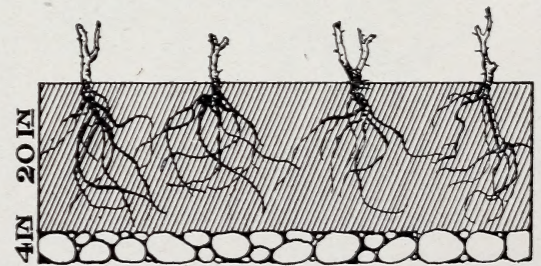

Layers of stones like this are not essential if the ground is naturally well drained 


\section{The 25est hroses in America 卖}

in water; if the stems have dried out, bury the whole plant, after soaking the ball, in damp earth for several days. This treatment may put them in good condition, while, if they are planted when dried out, there is more danger of their dying.

Planting. When ready to plant, unpack the plants in a shaded place, protected from the wind. Keep the roots covered with damp burlap, moss or other material until the actual moment of planting; spring winds are so drying that fatal damage may occur through a few moments of exposure. Do not set the plants too deep or too shallow. If planted too deep, the stems will rot off; if too shallow, the plant will grow spindling, will dry out too soon, and high winds will cause them to sway, breaking the roots. It is a good rule to plant them just a little deeper than they formerly grew, with upper roots one or two inches under ground. Make the hole in which the plant is to be set large enough so that the roots can be spread out naturally. Plants with cramped roots never do so well as those that have plenty of root-room when planted. Use plenty of water when planting, to work the soil in among the roots. As the soil is being thrown in about the ball, pour in a pailful of water. When the hole is almost full, pour in another pailful, then set the next plant. In three or four hours, when the surplus water has drained away, finish filling the hole with soil and TRAMP the earth firmly about the plant. The after-cultivation consists of frequently stirring the surface soil to maintain a dust mulch - about once a week and as soon as possible after each rain will be sufficient.

Enemies of the Rose. The price of perfect flowers is eternal vigilance, for there are many insect pests and plant diseases that must be fought constantly. The worst enemy is the Rose beetle which is particularly severe on sandy soils. Damage from this pest can be greatly lessened by spraying every two weeks through June and early July with arsenate of lead at the rate of one pound to ten gallons of water. In seasons when only a few appear, hand-picking may be resorted to. If the arsenate of lead is applied to the under side of the leaves it will also hold the Rose slug in check. The presence of this insect will be recognized by the skeletonized leaf. Aphis attack the plants during May and June, but damage from this source can be obviated by spraying with Thompson's Rose Nicotine, or with kerosene emulsion. This latter insecticide, strange as it may seem, acts as a fungicide, preventing mildew, one of the bad Rose pests.

Leaf-spot, mildew, rust and other fungous diseases can be held in check or prevented by spraying every two weeks with Bordeaux mixture, or, if you object to the grayish green spotting of the leaves, use an ammoniacal copper carbonate solution, or apply Grape Dust (see p. 34).

Cultivate the garden once a week up to the middle of July to maintain a dust mulch on the bed, so as to conserve soil moisture. After that a mulch of welldecayed manure, in which no heat will generate, may be given the bed.

In the fall, upon the approach of heavy frosts, protect the plants by giving them a mulch about the stems. This may easily be done by piling soil up around the stems to the depth of five or six inches. In the case of the Teas and Hybrid Teas, it will also be wise to protect the stems by straw, but this should not be done until after the ground has frozen; then the ground mice will have provided themselves with homes for the winter. The straw can either be tied about each plant, or the canes bent down and the whole bed covered with straw.

The best protection against insect attacks is vigorous health. Roses that are full of vigor are seldom full of bugs! Therefore, keep your Roses healthy and happy.

Pruning. If you have bought two- or three-year-old plants, cut them back rather severely at the time of planting - to three or four buds on the Hybrid Perpetuals and about six on the Teas and Hybrid Teas. Always cut the stem just above a bud that points out, never above one that points toward the center of the plants. The term bud or eye is used to define the places on the stem where leaves will be produced. They are easily distinguished, as they look like small, pointed warts on the stems. If the plants are in leaf when planted, THE ABOVE DOES NOT APPLY. The crop of flowers on the Rose plants is largely governed by the kind of pruning the plants receive. In fact, other conditions being ideal, the pruning determines the quantity and the size of the flowers.

The Hybrid Perpetuals and other hardy and Climbing Roses should be pruned in March, if weather permits, by the middle of the month. The tender Roses, the Teas and Hybrids, need not be pruned until along in April, when the sap begins to flow and the buds begin to swell, for, at this time, dead and weak wood may be much more easily distinguished and cut out than earlier in the season. 


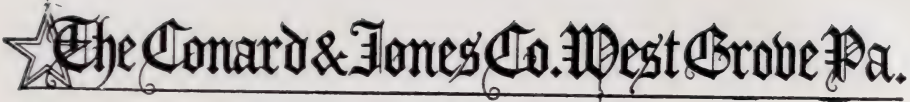

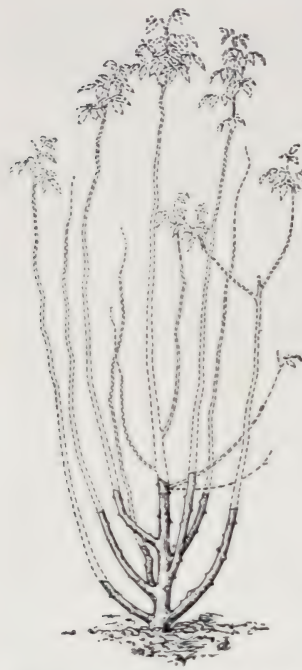

Showing where to prune

Besides, it is an advantage to leave the mulch undisturbed until settled weather has arrived. At the time of pruning, one must decide upon the kind of crop wanted. If the very biggest and best FLOWERS are wanted, then severe pruning is necessary (see I below); if large crop of average flowers, then only moderate pruning (see 2 below); but, where quantity of bloom is preferred, only a little pruning is necessary (see 3 below).

When pruning Hybrid Perpetuals, first cut out the weak wood and any branches that cross, then cut back the strong canes to about six eyes, the top one pointing out, and the cut being made one-quarter of an inch above the bud. If you want only a few big flowers, cut back to only three or four buds. For the big outdoor display, leave four to seven canes two-thirds their growth. The Teas and Hybrid Teas will need the same attention, but there should be as much or more wood left. This may not always be possible, however, as the winter may have killed the canes back too far. In that case, cut back to live wood, even if down to the surface of the soil.

These rules are modified somewhat by the character of the plant. The weaker-growing varieties can be cut back farther than strong-growing sorts. The strong-growing kinds, if cut back too heavily, will run to wood, and in the case of some-Gloire Lyonnaise, for instance-too heavy pruning may kill the plant.

The Bourbon Roses need but little pruning. Cut back the stems a few inches.

This is also true of the Brier Roses, such as Harrison's Yellow and the RAMBLERS, which should not be pruned much in the fall or spring, BUT JUST AFTER THE FLOWERING SEASON, to produce wood for next season's bloom.

Climbing and Pillar Roses need be cut back but one-third to one-fifth, and on old well-established plants, the old, enfeebled wood should also be taken out.

A LITTLE TRICK to prevent the bare base of the branches: In straight branches, the sap goes to the top, leaving nothing for the buds at the base. Train the branches up crooked by putting sharp bends in the stems within two feet of the ground, and foliage will be produced the whole length of the stem. To get a second crop of flowers in the fall, cut eight to ten inches of wood with the flowers. Several Hybrid Perpetuals will also bloom in the fall with this treatment. See also below and the list of ror Roses on pages 13 to 24

IN THE FALL, extra-long canes will need to be cut back a little, and perhaps tied to a stake or support, to prevent damage to the roots from swaying.

\section{HOW TO PRUNE (Key to pages $I_{3}$ to 24)}

These notes may be considered as abbreviations to the chapter on pruning. I. HARD. - Thin out to the base all but from three to five shoots, and cut these back so as to leave two to three eyes on each shoot.

2. MODERATELY HARD. - Thin out as No. I, and cut each shoot back to about five to ten eyes.

3. MEDIUM. - Thin out as No. I, leave four to seven shoots; shorten these shoots to about half their length.

4. SPARINGLY.- Thin out as No. I; leave four to seven shoots, which should be merely tipped.

5. THIN.-No pruning required; thin out annually.

6. NONE.-No pruning required; thin out every two or three years, just to keep the plant within bounds.

7. Climbing, Pillar and all other Roses that are marked 7 can be improved by thinning, when one or more of the old stems shows plainly that it is old and past doing good service. This should not be necessary of tener than every three years. Kinds marked + are more likely to need it than kinds marked - .

None of the numbers cover the needs of such Roses as Mrs. Peary, Marechal

Niel, etc., where the climate is warm enough not to kill back the main stems. In this case, the branches should be trimmed to two to ten eyes.

$\mathrm{X}$. Method to use to produce FINE SPECIMENS or large flowers.

S. Method to use to produce SHOWY BUSHES or an abundance of flowers. 


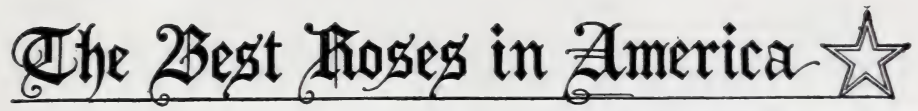

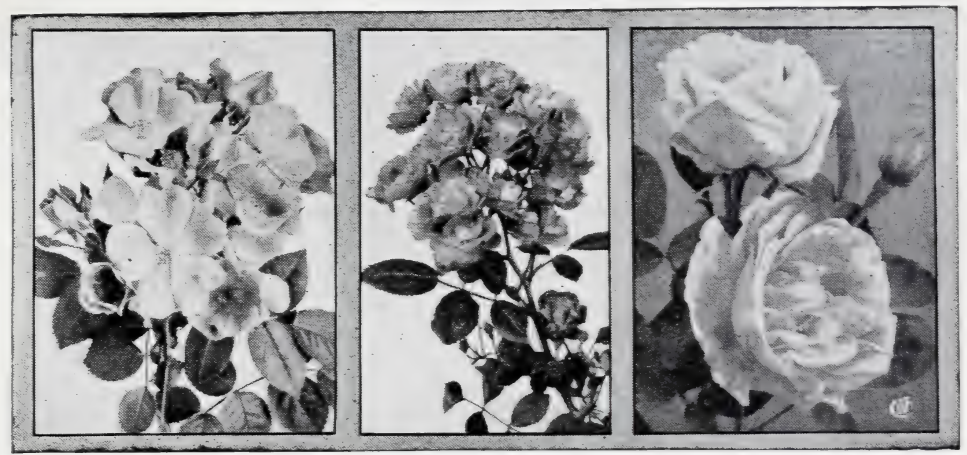

American Pillar (p. I3)

Baby Rambler (p. 13)

Anna de Diesbach (p. I3)

\section{STAR CATALOG OF ROSES}

\section{"What Varieties Shall I Plant?"}

This is the vital question. There are about ro,ooo varieties in all, so that much of your success and satisfaction will depend upon having this question properly answered.

Prof. Liberty H. Bailey, of Cornell University, and editor of the Cyclopedia of American Horticulture, says: "The success of the Rose in this country is very largely a question of the selection of adaptable varieties."

Pemberton, in his excellent work on "Roses," says to beginners, "State your requirements to a friend who is an expert, and leave the selection to him." Many of our customers do "leave the selection to us"-even from far-off Bagdad, in Asia, come orders asking us to select Roses "suitable for that country."

It is fun to select for oneself, however, if one can, and you can if you follow closely the next five pages.

Do you live in a temperate climate or a very cold one, or is your garden in the sunny Southland, where the Frost King never reigns? Because some members of this wonderful Rose family are very sensitive to frost. If you want Roses for bedding purposes, you will want kinds that will, (I) with protection, live outdoors over winter in your locality; (2) they should be reasonably dwarf (not pillars or climbers), and (3) you will probably want them as free-flowering as possible.

The following sets contain the pick of the Roses which have measured up to requirements like the above, and kinds which have proved themselves "best by test," in our own and the gardens of our patrons almost everywhere.

The important characteristics of each Rose will be found in the following descriptions. The following explanations will help you to more fully understand the terms used. We state after the name of each Rose-

(I) The Class to which it belongs. (2) The Color of the flower. (3) The Character of the Leaves when they are particularly worthy of mention. (4) The Character of Growth (vigorous, moderate, etc.). (5) The Purposes for which best

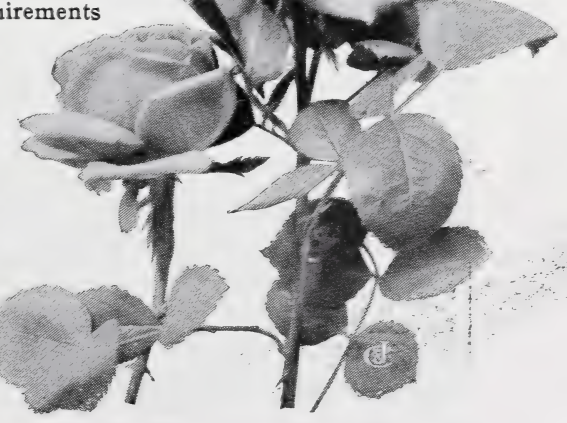

The Great American Beauty (p. I3) 


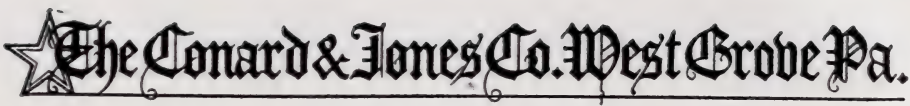

suited. (6) The way to prune the variety. (7) Other noteworthy remarks. (8) Price. One-year plants are sent postpaid. The others will be sent express collect. We will, however, send them express prepaid provided five cents is added for each plant ordered. We strongly advise this form of transportation.

After the name of the variety, the Class to which it belongs is indicated by the following abbreviations:

T. Tea Roses

H.T. Hybrid Tea

B.C. Bourbon China

P. Polyantha

T.P. Tea-scented Polyantha

C.T. Climbing Tea

C.H.T. Climbing Hybrid Tea
H.P. Hybrid Perpetual

H.R. Hybrid Rugosa

M. Moss

H.C. Hardy Climber

W. Wichuraiana

H.W. Hybrid Wichuraiana

A. Austrian Briers

Of the above, the last seven classes include the hardiest Roses; they will live out over winter in our temperate climate without protection, but all Roses will be better for some protection. The classes in the first column require careful protection, especially the Teas. The first seven classes named above comprise the varieties which bloom most continuously throughout the summer and fall.

The Character of Growth is indicated upon a scale arranged as follows: Weak, moderate, moderately vigorous, vigorous, very vigorous; "robust" indicates sturdy and bushy, but short growth. Climbers are described either as vigorous climbers, suitable for low pillar or trellis, or very vigorous, suitable for archways, pergolas, or high trellis.

\section{The Name Explaining Purpose for Which Roses}

\section{are Suited (Key to pages I3 to 24)}

Garden-Recommended for general lawn or garden cultivation.

Bedding -i. e., free-flowering and of rather compact growth, - good for massing in beds, either several of a kind or with other bedding Roses.

Pillar.-Excellent for training up to a low pillar, stake or post.

Arch.-For covering an archway.

Pergola.-For growing over a pergola.

Wall. - Suitable for training up the face of a wall or side of a building.

Creeping.-Good for covering a bank, stumps, rocks, etc.

Trellis.-Grows well on a trellis.

Bush.-Makes a good bush when planted alone and allowed to develop.

Pot or Cut-Flowers. - Those that have particularly long stems and other qualities that make them peculiarly fitted for cutting. Good also under glass.

Edging. - Makes an excellent edging to a Rose bed or other border.

Hedge.-Adapted for making a hedge, either all one kind or with others.

Tree or Standard. - Kinds that do well in tree form, as illustrated on page 28.

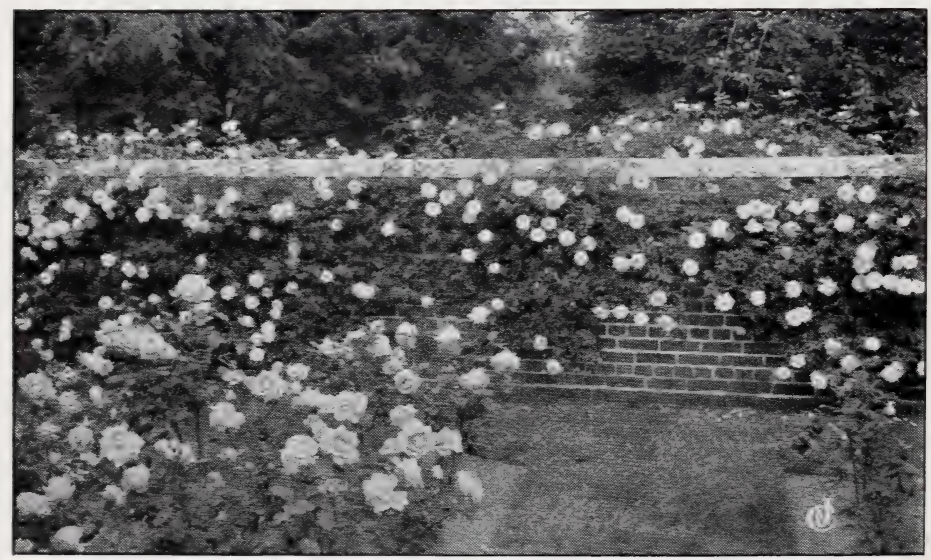

This is Gardenia (p. I6) running in revelry over the garden wall 


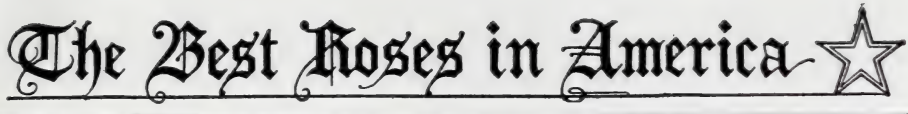

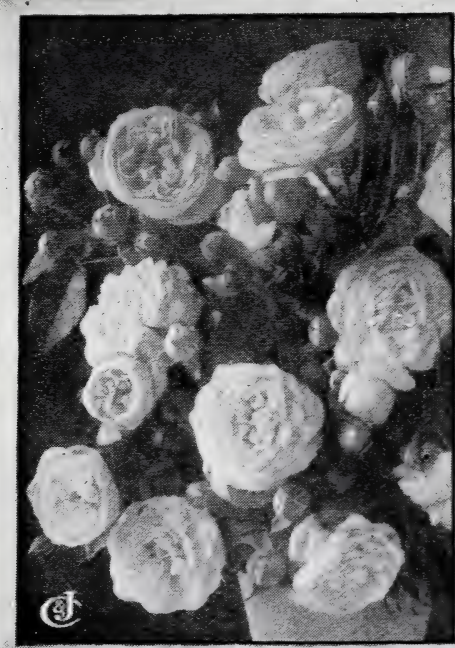

Clotilde Soupert (p. I4)

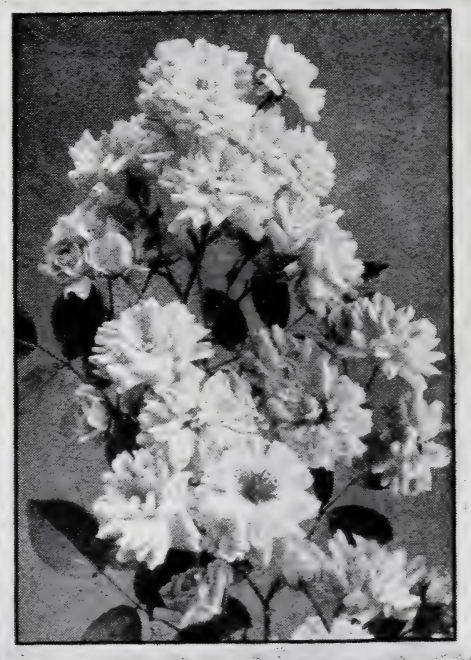

Dorothy Perkins (p. I5)

\section{ONE-HUNDRED-AND-ONE BEST ROSES}

Loving Roses as we do; living among them and watching them closely and constantly, under all sorts of conditions; having before us reports upon Roses from every country on earth to which our Roses go, and knowing, too, the Prize Winners and kinds that have pleased amateurs here and almost everywhere; watching the new Roses as they "come out," testing all kinds and holding fast to those which are good, - out of an experience like that has come our choice of these Ior Roses.

ALBA RUBIFOLIA. (H.W.) Fls. pure white, fragrant. Lvs. shining, almost evergreen. Vigorous, semi-creeping. Prune 6,7 .

I-yr. I5c., postpaid; by express, 2-yr. 35c., $\star$-size $50 \mathrm{c}$.

ALICE ALDRICH. (H.R.) Fls. bright pink. Lvs. leathery and oddly wrinkled: robust and vigorous. Garden. Prune 6, 7 .

I-yr. 25c., postpaid; by express, 2-yr. 50c., $\star$-size $\$ r$.

AMERICAN BEAUTY. (H.P.) Fls. deep rich pink, very fragrant. Lvs. large, roundish. Pot, standard. Prune $I$ for $x, 3$ for $s$. (See cut page II.)

I-yr. 25c., postpaid; by express, 2-yr. 40c., $\star$ size $60 c$.

American Pillar. (H.C.) Fls. chaste pink, single, large ( 3 to 4 in. across)

in large clusters. Lvs. almost evergreen; never troubled with insects. Very vigorous. Pergolas, pillars, etc. Prune 6, 7. Has attractive, brilliant red hips in autumn. (See front cover.)

I-yr. 25c., postpaid; by express, 2-yr. 5oc., $\downarrow$-size $\$$ I.

ANNA DE DIESBACH. (H.P.) Fls, rose, large, very full, fragrant; profuse bloomer. Garden. Prune I for $\mathbf{x}, 3$ for s. (See cut, p. Ir.)

I-yr. I5c., postpaid; by express, 2-yr. 35c., $\star$-size $60 c$.

BABY DOROTHY. (P.) Fls: bright pink; incessant bloomer, often having Ioo to 200 blossoms. Dwarf, 20 in. Bedding, edging. Good companion to the dainty and vigorous Baby Rambler. Prune 3. Awarded gold medal as a superior variety at Orleans, France.

I-yr. 25c., postpaid; by express, 2-yr. 50c., $\star$-size $75 \mathrm{c}$.

Baby Rambler. (P.) Fls. rosy crimson, 20 to 30 in a cluster; blooms Baby Rambler. continuously. Lvs. dark glossy green, free from insects. Dwarf. Bedding, edging and standard. Prune 3. (See cut, p. II.)

I-yr. I5c., postpaid; by express, 2-yr. 35c., $\star$-size $60 \mathrm{c}$.

FOR EASY SELECTION, see special sets on pages 24 to 33

I3 See Explanatory Key on pages 11 and 12 


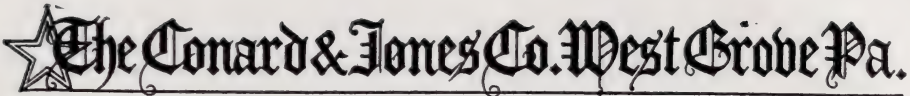

BARON DE BONSTETTEN. (H.P.) Fls. velvety maroon, shaded with deep crimson, delightfully fragrant; extra-large, solid, round and full. A very satisfactory June Rose. Vigorous. Garden. Prune 2.

I-yr. I5c., postpaid; by express, 2-yr. 35c., $\nless$-size, 6oc.

BARONESS ROTHSCHILD. (H.T.) Budded only. Fls. rich satiny pink, large, full; a truly noble Rose. Garden. Prune I for $x, 3$ for s. By express, 2-yr. 35c., $\star$-size 6 oc.

B E A U T Y OF ROSEMAWR. (B.C.) Fls. c a r $\mathrm{m}$ in e, shaded creamy white, delightfully fragrant, b $100 \mathrm{~ms}$ continuously. Vigorous. Bedding, pot,garden. Prune 4. I-yr. I5c., postpaid; by express, 2-yr.35c., $\star$-size 6 oc.

Bessie Brown.

(H.T.) Fls. shell-pink, large, full, of extraordinary depth, fragrant. Garden, bedding. Prune 2 for South, 4 for North. Has won 32 medals in less than five years. I-yr. 20c., postpaid; by express, 2 -yr. 40c.. $\star$-size $60 c$.

BIRDIE BLYE. (H.C.) Fls. bright satiny rose, fairly double, fragrant; buds long, pointed; continuous free bloomer. Lvs. glossy. Vigorous, 3 to $4 \mathrm{ft}$. Pillar.

Prune 5. Hardy almost everywhere in the temperate zone.

I-yr. 25c., postpaid; by express, 2-yr. 5oc., $\star$-size $75 \mathrm{c}$.

BRIDE. (T.) Fls. pure white, sometimes tinted blush. Bedding, cut-flower. Notable for its use by florists. Prune 2 for $\mathrm{x}, 4$ for $\mathrm{s}$.

I-yr. Ioc., postpaid; by express, 2-yr. 30c., $\star$-size, 6oc.

BRIDESMAID. (T.) Fls. rose-pink, crimson shaded, full and fragrant. Bedding, cut-flower. Prune 2 for $\mathrm{x}, 4$ for $\mathrm{s}$.

I-yr. Ioc., postpaid; by express, 2-yr. 30c., \-size 6oc.

CAPT. HAYWARD. (H.P.) Fls. bright crimson-carmine, large, full and very sweet. Garden, bedding. Prune $I$ for $x, 3$ for s.

I-yr. I5c., postpaid; by express, 2-yr. 35c., $\star$-size $60 \mathrm{c}$.

CECILE BRUNNER. (P.) Fls. blush, deep salmon center, fragrant; among the largest in the Polyantha class; free bloomer. Garden, bedding and edging. Prune 4. A great favorite in its useful class.

I-yr. Ioc., postpaid; by express, 2-yr. 30c., $\star$-size $60 c$.

Clio (H.P.) Fls. flesh color, shaded pink; large, fine form. Very vigorous. (H.P.) Fls. flesh color, shaded pink; large, fine form. Very vigorou
Garden. Prune I for $x, 3$ for s. A very choice variety. (See cut.) I-yr. I5c., postpaid; by express, 2-yr. 35c., $\star$-size $60 \mathrm{c}$.

CLOTILDE SOUPERT. (T.P.) Fls. creamy white, tinged with pink, fragrant; free bloomer. Vigorous. Edging, bedding. Prune 4. Blooms until frost.

I-yr. Ioc., postpaid; by express, 2-yr. 30c., $\star$-size $60 c$.

COMTESSE DE MURINAIS. (M.) Fls. pure white, large, full, fragrant; a good bloomer. Bedding. Prune 2. (See cut, p. 22.)

I-yr. 20c., postpaid; by express, 2-yr. 4oc., $\star$-size $60 c$.

CONRAD F. MEYER. (H.R.) Fls. clear silvery rose, large, perfectly double, elegantly formed, very fragrant; fls. and buds of fine form. Garden, bush or hedge. Prune $6+$. Very hardy.

I-yr. 40c., postpaid; by express, 2-yr. 75c., $\star$-size $\$$ I.50.

FOR EASY SELECTION, see special sets on pages 25 to 33

See Explanatory Key on pages 11 and 12 I4 


\section{The 2 sest Hoses in America trs}

COQUETTE DES ALPES. (H.P.) Fls. pure white, tinged with blush; large, cupped form, free-flowering. Garden. Prune 2 for $x, 3$ for s.

I-yr. I5c., postpaid; by express, 2-yr. 35c., $\star$-size $60 \mathrm{c}$

COUNTESS OF GOSFORD. (H.T.) Fls. salmon-pink, base of petals saffron; perfect form, large, full, fragrant; has the odor of peaches; buds long, pointed; free bloomer. Garden. Prune 2. Awarded the high honor of a gold medal by the National Rose Society of England.

I-yr. 2oc., postpaid; by express, 2-yr. 40c.

CRIMSON RAMBLER. (H.C.) Fls. intense crimson; large clusters all over the plant. Very vigorous, of ten $\mathrm{I}_{5} \mathrm{ft}$. in a season. Trellises, pergolas, etc. Prune $6,7+$. Thrives everywhere.

r-yr. I5c., postpaid; by express, 2-yr. 35c., extra 2-yr. size 5oc., $\star$-size $80 \mathrm{c}$.

Dorothy Perkins. (H.C.) Fls. beautiful shell-pink; free bloomer; large clusters. Almost evergreen. Very vigorous. Arches, porches, pergolas, etc. Prune 6, $7-$. Most popular Rose in its class and color, and blooms just in time for use at June weddings. (See cut, p. 29.) I-yr. I5c., postpaid; by express, 2-yr. 35c., extra 2-yr. size 50c., $\star$-size $80 \mathrm{c}$.

DUCHESSE DE BRABANT. (T.) Fls. deep rosy pink, edged with silver. Bedding. Prune 4. Has been extensively planted about the "White House" at Washington, D. C., and is a lovely and free-blooming variety.

I-yr. Ioc., postpaid; by express, 2-yr. 30c., $\star$-size $60 c$.

EMPRESS OF CHINA. (H.C.) Fls. soft deep rose, passing to pink; free bloomer. Very vigorous. Arches, trellises, etc. Prune 5. Rapid grower; valuable climber. Thrives everywhere, and gives much pleasure.

I-yr. I5c., postpaid; by express, 2-yr. 35c., $\star$-size 6 oc.

ETOILE DE FRANCE. (H.T.) Fls. intense, brilliant crimson; extra large, double; very free bloomer; very fragrant; buds large, pointed. Vigorous. Bedding. Prune 2. A choice variety.

I-yr. 20c., postpaid; by express, 2-yr. 40c., $\downarrow$-size $60 c$.

ETOILE DE LYON. (T.) Fls. bright sulphur-yellow; very double; fragrant. Vigorous. Bedding. Prune 4. One of the best yellow bedding Roses.

I-yr. IOc., postpaid; by express, 2-yr. 30c., $\star$-size $60 \mathrm{c}$.

FLORENCE PEMBERTON. (H.T.) Fls. creamy white, suffused pink; large, full, perfect form; high-pointed center. Bush, garden. Prune 2. A Dickson Rose. Awarded gold medal by Nat. Rose Society of England; silver medal by Society of American Florists. One of the best new Roses.

I-yr. 20c., postpaid; by express, 2-yr. 40c, $\star$-size 60 .

FRANCOIS LEVET. (H.P.) Fls. rosy crimson, fragrant; free bloomer. Vigorous. Prune $I$ for $x, 3$ for $s$. One of the finest H. P. Roses.

I-yr. I5c., postpaid; by express, 2-yr. 35c., $\star$-size $60 c$.

Frau Karl Druschki. (H.P.) Fls. pure snow-white, immense (4 to 5 ous, Bedding, bush, in. across), perfectly double, fragrant. VigorThe finest hardy, pure white Rose yet introduced. Cannot be too strongly commended; also properly called the "White American Beauty." (See cut.) I-yr. 25c., postpaid; by express, 2-yr. 50c., $\star$-size $\$$ I.

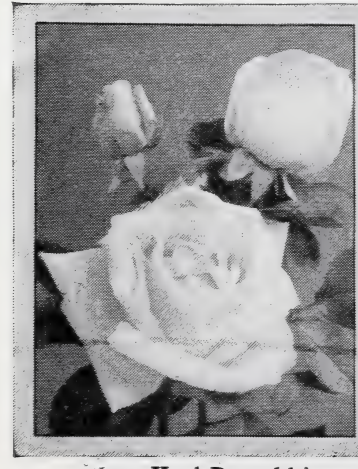

Frau Karl Druschki

(See also back cover)

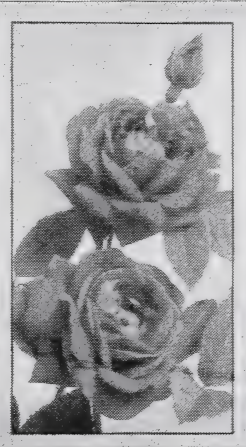

Gen. Jacqueminot (p. I6)

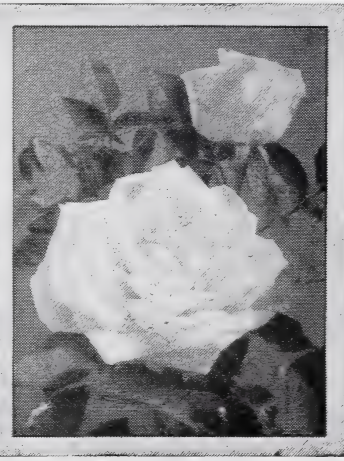

Gloire Lyonnaise (p. I6)

I5 See Explanatory Key on pages 11 and 12 


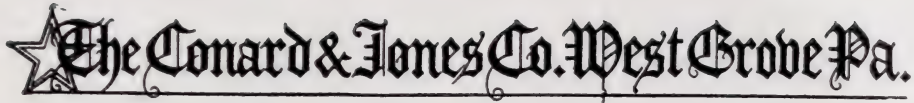

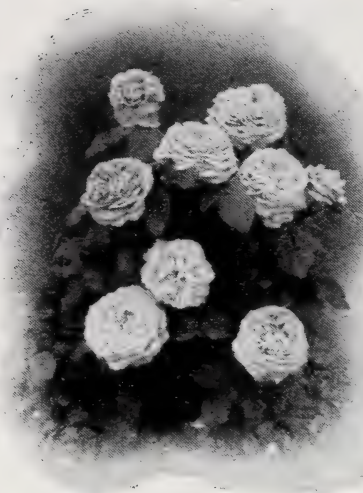

John Hopper (p. 17)

FREIHERR VON MARSCHALL. (T.) Fls. dark crimson, large, full, of perfect, imbricated form; beautiful, pointed bud. Vigorous. Garden. Prune 2 for $\mathrm{x}, 4$ for s. I-yr. 2oc., postpaid; by express, $2-y r .40 c ., ~ \star$-size $60 c$.

GAINESBOROUGH. (H.T.) Fls, rosy fleshcolored, tinged with salmon; large, very sweet, double and free. Very vigorous. Pillar. Prune 3 for $x, 4$ for $s$ r-yr. I5c., postpaid; by express, 2-yr. 35c., $\star$-size $60 c$.

GARDENIA (Hardy Marechal Niel). (H.W.) Fls. yellow, changing to creamy white; fragrant; free bloomer. Very vigorous. Creeping. Prune $6,7-$. I-yr. I5c., postpaid; by express, 2 -yr. 35 c., $\star$-size 75 c.

GENERAL JACQUEMINOT. (H.P.) Fls. brilliant crimson, velvety, fragrant. Vigorous. Bedding, garden, pot and standard. Prune 2 for $x, 3$ for $s$. (See cut, p. 15.)

I-yr. 20c., postpaid; by express, 2-yr. 40c., $\downarrow$-size $60 c$.

GLOIRE LYONNAISE. (H.P.) Fls. pale lemon; large. Very vigorous. Garden, bedding. Prune 2 for $\mathrm{x}, 3$ for s. A grand Rose, the nearest to yellow of any of the Hybrid Perpetual. (See cut, p. 15.)

I-yr. I5c., postpaid; by express, 2-yr. 35c., $\star$-size $60 c$.

Gruss an Teplitz. (H.T.) Fls. bright crimson; free bloomer. Vigorous.

Garden, bedding, bush and standard. Prune 5. A continuous bloomer; hardy. One of the most valuable red Roses ever introduced. Gives a superb effect in masses. (See cut.)

I-yr. I5c., postpaid; by express, 2-yr. 35c., $\downarrow$-size $60 c$.

HELEN GOULD. (T.) Fls. rich vinous crimson; free and continuous bloomer. Vigorous. Bedding. Prune 2 for $x, 4$ for s. A very popular, hardy, everblooming Rose, well worth a favored place

I-yr. 25c., postpaid; by express, 2-yr. 50c., $\star$-size $75 \mathrm{c}$.

HENRI MARTIN. (M.) Fls. bright rosy red, fragrant, large; free bloomer. Vigorous. Prune 3. Fine in its class.

I-yr. 20c., postpaid; by express, 2-yr. 40c., $\star$-size $60 c$.

HERMOSA. (B.C.) Fls. pink, in clusters; fragrant; free bloomer. Vigorous. Garden, bedding and standard. Prune 3. Well-known variety.

I-yr. roc., postpaid; by express, 2-yr. 30c., $\star$-size $60 c$.

HUGH DICKSON. (H.P.) New. Fls. brilliant crimson, shaded scarlet; very large and full; fine form. Free-flowering and vigorous. Highly perfumed. Garden. Prune I for $x, 3$ for s. I-yr. 25c., postpaid; by express, 2-yr. 50c., $\star$-size \$I.

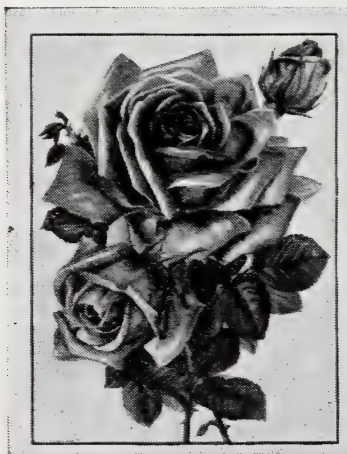

Lyon Rose (p. 20)

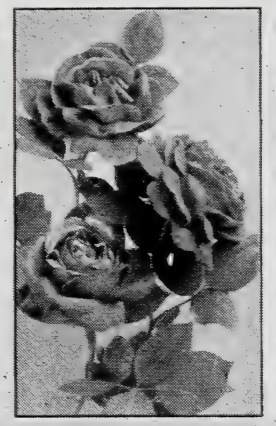

Gruss an Teplitz

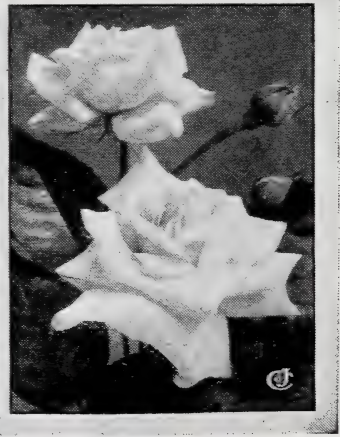

Kaiserin Augusta Victoria (p. I7)

See Explanatory Key on pages 11 and $12 \quad 16$ 


\section{The 20st Hoses in America-}

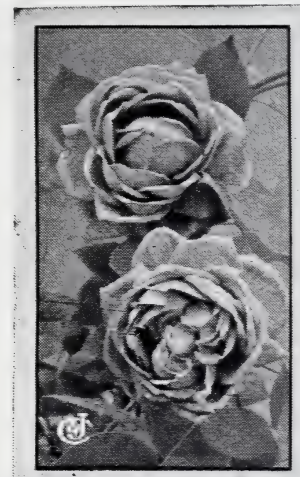

Magna Charta (p. 2r)

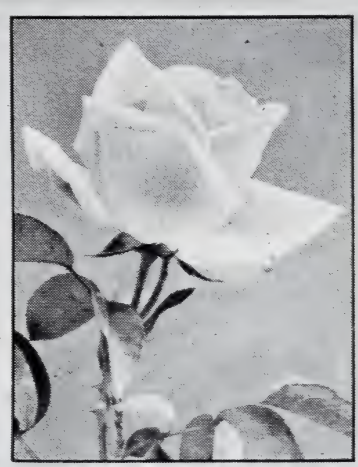

Killarney

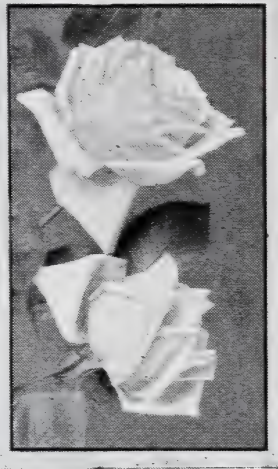

La France

JOHN HOPPER. (H.P.) Fls. bright rosy pink, very double, solid, fragrant; free bloomer. Vigorous. Bedding. Prune $I$ for $\mathrm{x}, 2$ for s. Good fall bloomer ; one of the very best in its class (See cut, p. I6.)

I-yr. I5c., postpaid; by express, 2-yr. 35c., $\downarrow$-size $60 \mathrm{c}$.

JUBILEE. (H.P.) Fls. dark velvety crimson; fragrant; free bloomer. Vigorous Bedding. Prune 2 for $\mathrm{x}, 3$ for $\mathrm{s}$. Said to be the best dark red introduced in forty years, and certainly a Rose of great merit.

I-yr. I5c., postpaid; by express, 2-yr. 35c., $\star$-size $60 c$.

Kaiserin Augusta Victoria. (H.T.) Fls. white, shading to lemon;

Vigorous. deep, full; fragrant; free bloomer. Vigorous. Garden; also cut-flower. Prune 3. Cannot be too highly recommended. (See cut, p. I6.) I-yr. I5c., postpaid; by express, 2-yr. 35c., $\star$-size 60 .

KILLARNEY. (H.T.) Fls. brilliant pink; long, pointed buds; free bloomer. Moderately vigorous. Garden, bedding, cut-flower. Prune 3. A great favorite. (See cut.) I-yr. 25c., postpaid; by express, 2-yr. 50c., $\star$-size $75 \mathrm{c}$.

LADY GAY. (H.C.) Fls. clear pink, fading to soft tinted white; free. Vigorous. Hardy and unsurpassed for climbing work. Arches, trellis. Prune 6,7 -. (See cut.) I-yr. I5c., postpaid ; by express, 2-yr. 40c., $\star$-size 8 oc

LA DETROIT. (H.T.) Fls. clear fleshpink, shading to deep rose; very full and delightfully sweet. Garden, bedding. Prune 2. I-yr. I5c., postpaid; by express, 2-yr. 35c., $\star$-size $60 \mathrm{c}$.

LA FRANCE. (H.T.) Fls. silvery rose, changing to pink; fine form, sweet, large; lovely buds. Moderate. Garden, bush, standard and cut-flower. Prune 2. (See cut.) I-yr. I5c., postpaid; by express, 2-yr. 35c., $\star$-size 60 c.

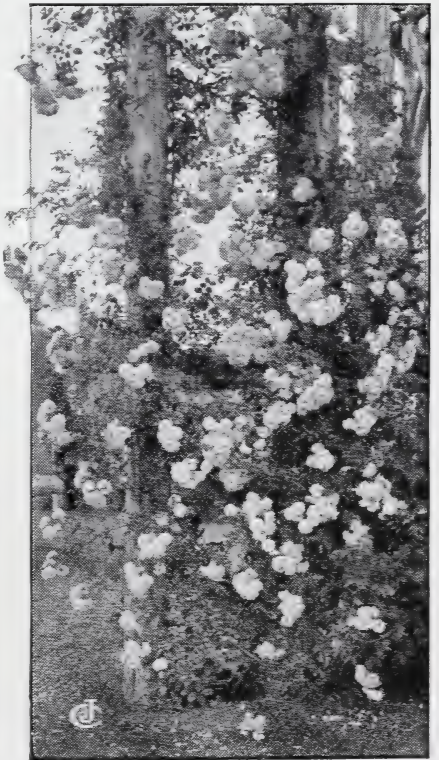

The Dainty Lady Gay

FOR EASY SELECTION, see special sets on pages 25 to 33

17 See Explanatory Key on pages 11 and 12 


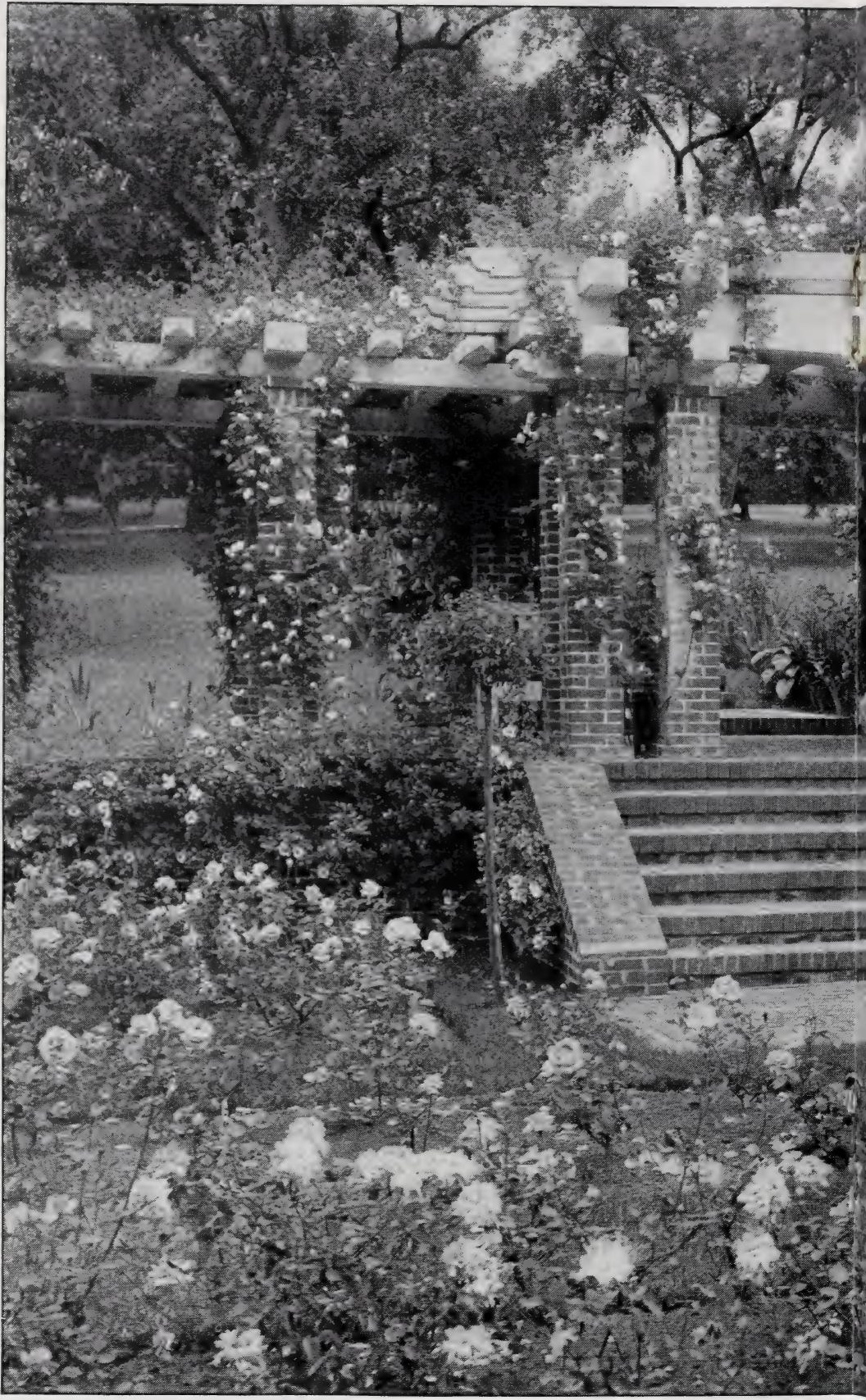

THE EFFECT OF ROSES ARRANGED BY

The unique pergola has Crimson Rambler, Dorothy Perkins and Wichuraiana, to complete its loveliness 


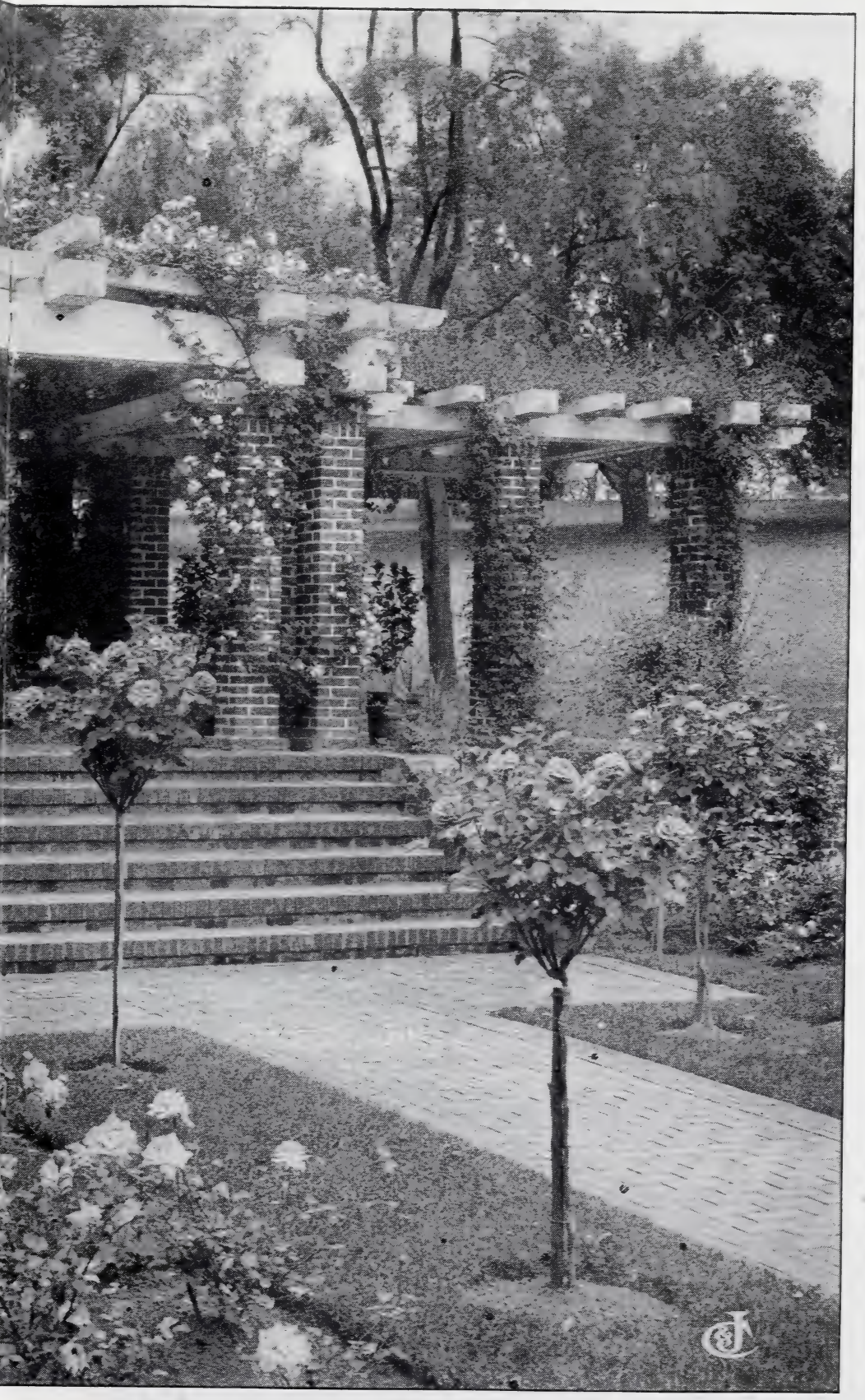

DESIGN, RATHER THAN AT RANDOM

The Tree Roses give a touch of formality, while the mass effect of the Maman Cochet in the beds is most pleasing 


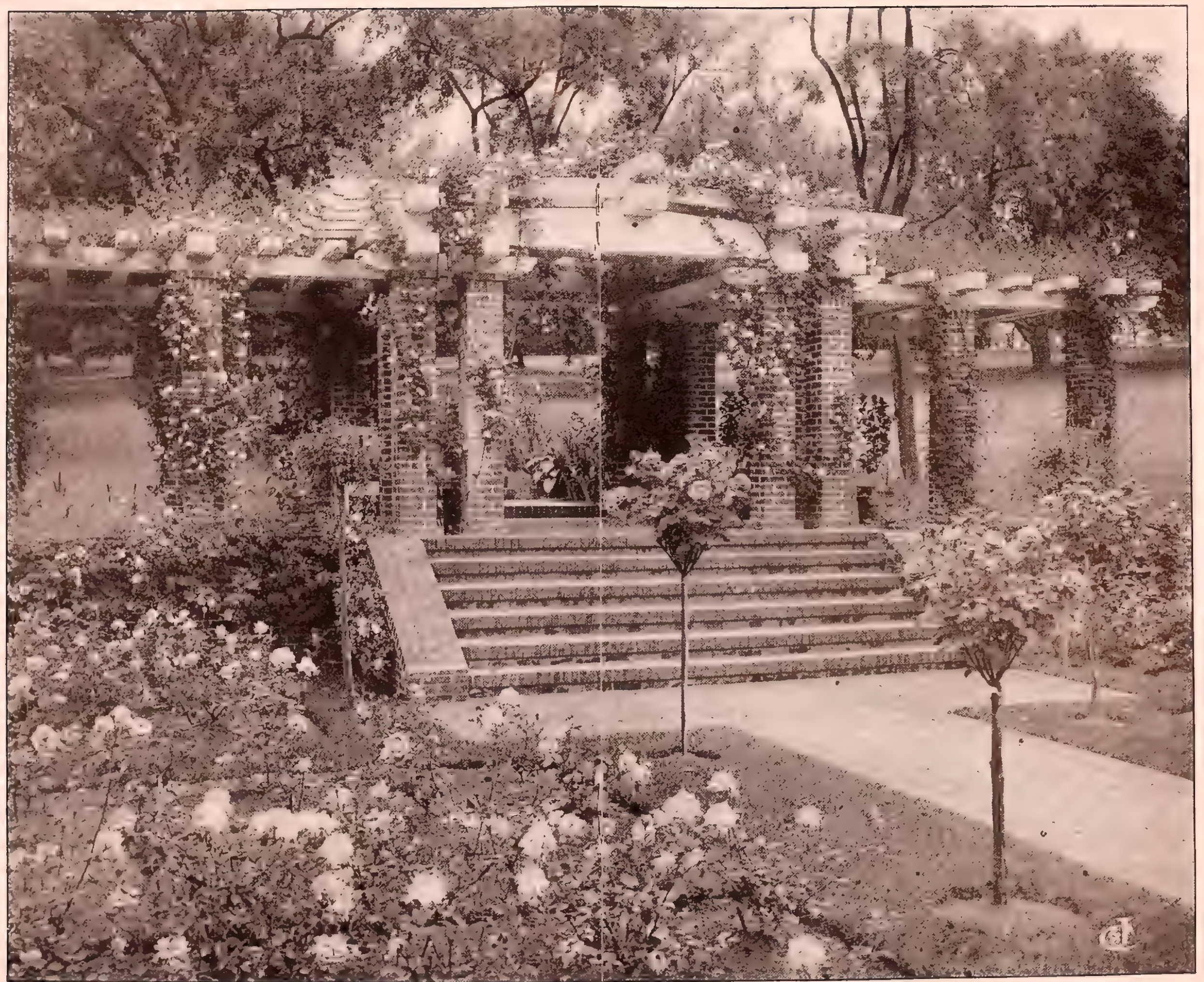

THE EFFECT OF ROSES ARRANGED BY DESIGN, RATHER THAN AT RANDOM

The unique pergola has Crimson Rambler, Dorothy Perkins and Wichuraiana, to complete its loveliness

The Tree Roses give a touch of formality, while the mass effect of the Maman Cochet in the beds is most pleasing 



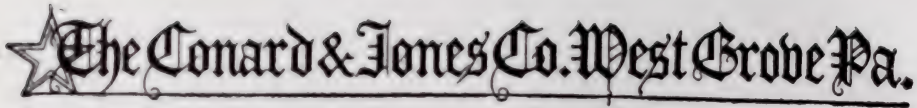

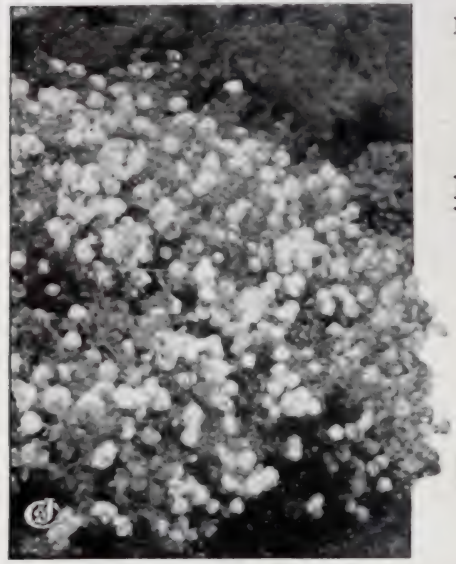

One bush of Mme. Plantier

LA TOSCA. (H.T.) Fls. rose; free bloomer. Vigorous. Garden, bush bedding. Prune 2 for $\mathrm{x}, 4$ for $\mathrm{S}$. A very satisfactory garden Rose. I-yr. 20c., postpaid; by express, 2 -yr. $40 c$., $\star$-size $60 c$.

Lyon Rose. (H.T.) Fls. salmon-pink shade chrome - yellow, full, globular, fragrant. Vigorous. Hardy. Bedding. Prune 3. Constant bloomer. Given roo points, and said to be beyond competition at great French test of 88 new varieties. (See cut, p. r6.) Choice plants, from 4-in. pots, SI, postpaid; by express, from 5-in. pots, \$r.5o.

Mme. Camille. (T.) Fls. flesh, changfull, sweet; con ing to salmon; large, ous. Bedding. Prune 2. I-yr. Ioc., postpaid ; by express, 2-yr. 30c., $\star$-size 6 oc.

Mme. Caroline Testout (H.T.) Fls. silvery rose, large, double, fragrant; free-bloomer. Vigorous. Garden, bedding and standard. Prune 2. (See cut.)

I- yr. I5c., postpaid; by express, 2-yr. 35c. $\downarrow$-size $60 c$.

MME. CHARLES WOOD. (H.P.) Fls. bright, rich cherry-red; constant bloomer; fragrant. Garden. Prune I for $x, 3$ for s.

I-yr. I5c., postpaid; by express, 2-yr. 35c., $\star$-size $60 \mathrm{c}$.

MME. EUGENE MARLITT. (B.C.) Fls. carmine-red, fragrant; free bloomer Vigorous. Bedding. Prune 4, tip severely. We believe this to be one of the best recent Roses.

I-yr. 25c., postpaid; by express, 2-yr. 50c., $\star$-size $75 \mathrm{c}$. MME. FRANCISCA KRUGER. (T.) Fls. pink, shading to yellow; full, double, fragrant. Buds fine, large. Vigorous. Bedding. Prune 2.

I-yr. roc., postpaid; by express, 2-yr. 30c., $\downarrow$-size $60 c$.

MME. LAMBARD. (T.) Fls. clear salmon-pink, passing to deep rose; profuse bloomer; very sweet. Bedding. Prune 3.

I-yr. Ioc., postpaid; by express, 2-yr. 3oc., $\star$-size $60 c$.

MME. MASSON. (H.P.) Fls. rich crimson; large, fragrant, free. Vigorous. Bedding. Prune $I$ for $\mathbf{x}, 3$ for $s$.

I-yr. 15c., postpaid; by express, 2-yr. 35c., $\downarrow$-size $60 c$.

MME. PLANTIER. (Hy. China). Fls. pure white; profuse. Vigorous. Bush or garden. Prune 5. Hardy. (See cut.) I-yr. 20c., postpaid; by express, 2-yr. 35c., $\star$-size $60 c$.
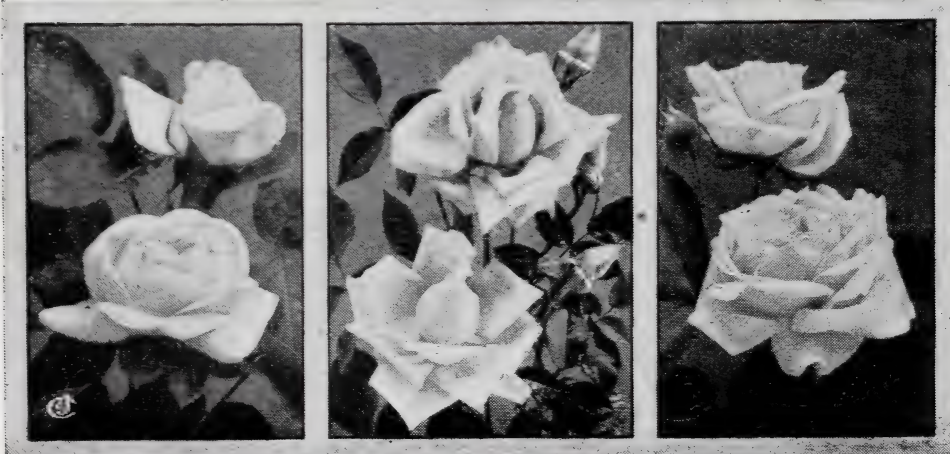

Margaret Dickson (D. 21)

Maman Cochet (p. 2I)

Mme. C. Testout

See Explanatory Key on pages 11 and 1220 


\section{The 25egt hoses in America th}

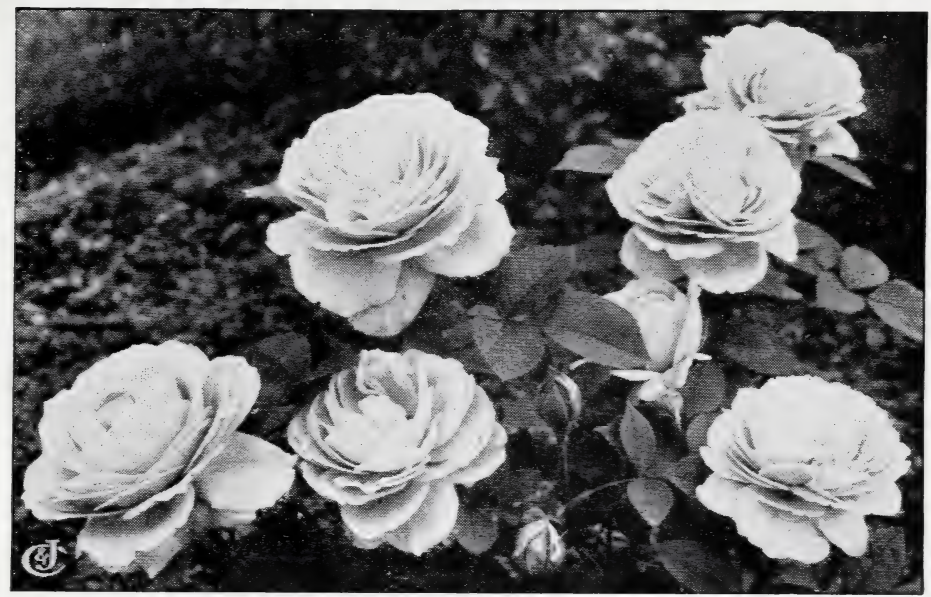

The famous blossoms of Mrs. John Laing (p. 22)

MAGNA CHARTA. (H.P.) Fls. pink, suffused with carmine; extra large, full, fragrant; free bloomer. Lvs. light green. Vigorous. Bedding. Prune 2 for $\mathbf{x}_{\text {, }}$ 3 for s. A choice variety. (See cut, p. I7.)

I-yr. I5c., postpaid; by express, 2-yr. 35c., $\star$-size $60 \mathrm{c}$

MAGNAFRANO. (H.T.) Fls. deep rose, fragrant; free bloomer. Vigorous A combination, seemingly, of two good Roses. Garden. Prune 2.

I-yr. 20c., postpaid; by express, 2-yr. 40c., $\star$-size $60 \mathrm{c}$

Maman Cochet. (T.) Fls. deep coral-pink, large, very double, full fragrant. Vigorous. Garden, bush. Prune 2. One of the largest and hardiest of its class. (See cut, p. 20.)

I-yr. I5c., postpaid; by express, 2-yr. 35c., $\star$-size $60 \mathrm{c}$

MANDA'S TRIUMPH. (H.W.) Fls. pure white, double, fragrant; medium size in clusters. Vigorous. Creeping. Excellent for cemetery. Prune 6, 7 I-yr. I5c., postpaid; by express, $2-y r$. 35c., $\downarrow$-size $50 \mathrm{c}$.

MARCHIONESS OF LORNE. (H.P.) Fls. bright shining rose, full, finely cupped; delightfully fragrant. Garden. Prune I for $x, 3$ for $s$.

I-yr. I5c., postpaid; by express, 2-yr. 35c., $\star$-size $60 \mathrm{c}$

MARECHAL NIEL. (C.T.) Fls. deep yellow; large, globular, full, sweet. Vigorous. Porch, pillar, pot, standard, etc. Prune 5. A most beautiful climber. Hardy only in the South. I-yr. I5c., postpaid; by ex oress, 2-yr. 35c., $\star$ size $60 c$.

MARGARET DICKSON. (H.P.) Fls. white, flesh center; petals large, shell-shaped. Vigorous. Bedding, garden. Prune I for $x, 3$ for s. An excellent Rose. (See cut, p. 20.) I-yr. I5c., postpaid; by express, 2-yr. 35c., $\star$-size 6oc.

MARIE VAN HOUTTE. (T.) Fls. pale yellow, edged with rose; large, full, fragrant. Vigorous. Bedding. Prune 2. Constant bloomer. One of the best for bedding. I-yr. I5c., postpaid; by express, 2-yr. $35 \mathrm{c}$., $\star$-size 6 oc.

METEOR. (H.T.) Fls. velvety crimson, fragrant, free. Vigorous. Bedding, pot. Prune 2. I-yr. I5c., postpaid; by express, 2-yr. 35c., $\star$-size 6 oc.

FOR EASY SELECTION, see special sets on pages 25 to 33

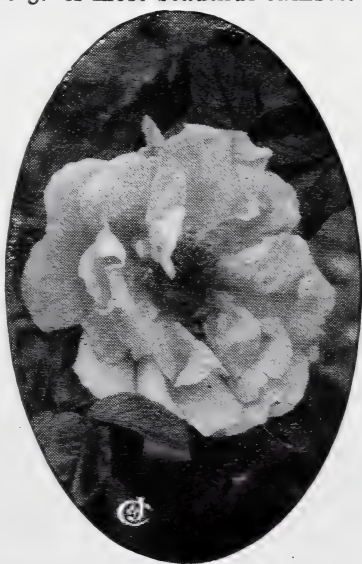

Rosa rugosa magnifica (p. 23)

21 See Explanatory Key on pages 11 and 12 


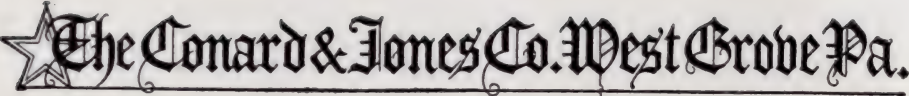

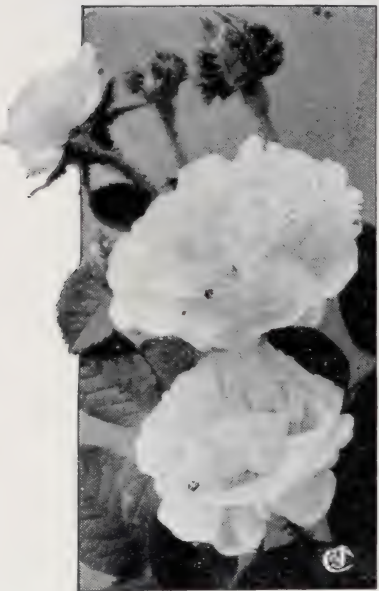

C. de Murinais (Moss) p. 14

MLLE. HELENA GAMBIER. (H.T.) Fls. canaryyellow, center tinted pink; large, double, sweet; a constant bloomer. Vigorous. Bedding. Prune 2 I-yr. I5c., postpaid; by express, 2-yr. 35c., $\star$-size $60 \mathrm{c}$

MOSELlA. (Climbing.) New I909. Our own introduction. Fls. golden yellow to cream. A vigorous climber and most free bloomer. Prune 3 for $\mathrm{x}, 5$ for s. I-yr. 35c., postpaid; by express, 2-yr. 75c., $\star$-size $\$$ I.25.

MRS. B. R. CANT. (T.) Fls. rose red, large, full, perfectly double, fragrant. Constant bloomer. Vigorous. Garden, bedding. Prune 3. I-yr. 25c., postpaid; by express, 2-yr. 50c., $\star$-size $75 \mathrm{c}$.

MRS. JOHN BATEMAN. (H.T.) Fls. deep China rose, with yellow at base of petals; freeflowering; fragrant. A very beautiful Rose. Bedding. Prune 2. I-yr. I5c., postpaid; by express, 2-yr. 35c., $\star$-size $60 \mathrm{c}$.

MRS. JOHN LAING. (H.P.) Fls. soft pink, large, full, fragrant, on long stems; free bloomer.

Vigorous. Garden, bedding, bush, pot and standard Prune $I$ for $\mathbf{x}, 3$ for s. (See cut, p. 2r.)

I-yr. I5c., postpaid; by express, 2-yr. 35c., $\star$-size $60 \mathrm{c}$

MRS. ROBERT PEARY (Climbing Kaiserin Augusta Victoria). (C.H.T.) Fls. white, tinted lemon, fragrant, on long stems; fine form. Buds excellent. Vigorous. Porches, trellis, etc. Prune 3 for $x, 5$ for $s$

I-yr. I5c., postpaid; by express, 2-yr. 35c., $\star$-size $60 \mathrm{c}$.

OAKMONT. (H.P.) Fls. bright rose, large, fragrant; free bloomer. Vigorous. Bedding. Prune 2 for $\mathrm{x}, 3$ for $\mathrm{s}$.

I-yr. I5c., postpaid; by express, 2-yr. 35c., $\downarrow$-size $60 \mathrm{c}$

PAUL NEYRON. (H.P.) Fls. deep rose, fragrant, opens flat. Vigorous. Bedding, garden or standard. Prune $I$ for $\mathrm{x}, 3$ for $\mathrm{s}$. The largest Rose. (See cut.)

I-yr. 20c., postpaid; by express, 2-yr. 40c., $\downarrow$-size $60 \mathrm{c}$ Philadelphia Rambler. (H.C.) Fls. intense crimson, double, in large Of the greatest merit as a climber. Prune $6-, 7+$. Hardy.

I-yr. 20c., postpaid; by express, 2-yr. 35c, extra 2-yr. 50c., $\star$-size $85 \mathrm{c}$.

PRINCE CAMILLE DE ROHAN. (H.P.) Fls, velvety crimson, large. Vigorous. Bedding. Prune 2 for $x, 3$ for s. One of the darkest colored Roses. (See cut.) I-yr. I5c., postpaid; by express, 2-yr. 35c., 丸-size 6oc.

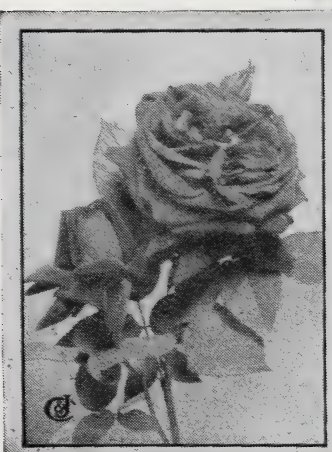

Prince Camille de Rohan

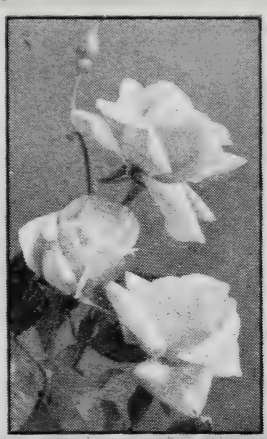

Safrano (p. 23)

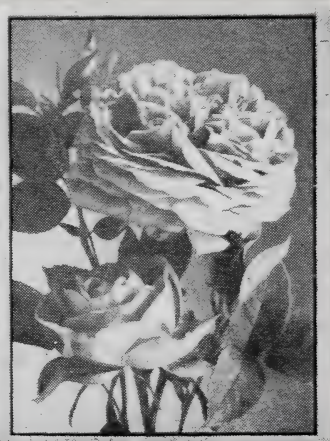

Paul Neyron

See Explanatory Key on pages 11 and $12 \quad 22$ 


\section{The 25est Hoses in America 光}

PRINCESS ADELAIDE. (M.) Fls. pale rose, large, double, fragrant. Vigorous. Garden. Prune 2. I-yr. 20c., postpaid; by express, 2-yr. 40c., $\star$-size 6 oc.

PURPUREA RUBRA. (M.) Fls. pink, large, very double, fragrant. Vigorous.- Garden. Prune 2. I-yr. 20c., postpaid; by express, 2-yr. 40c., $\star$-size $60 c$.

QUEEN ALEXANDRA. (H.C.) Fls. clear rose. Vigorous. Arches, pergolas, etc. Prune $6,7+$. I-yr. 20c., postpaid; by express, $2-y r$. $40 \mathrm{c}$., $\star$-size $75 \mathrm{c}$.

ROGER LAMBELIN. (H.P.) Fls. rich glowing crimson, with edge of petals pure white, like a Picotee; handsome. Garden. Prune $I$ for $x, 3$ for s.

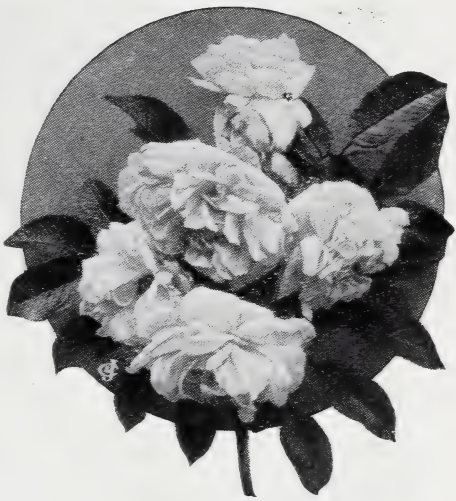

Sir Thomas Lipton

I-yr. 20c., postpaid; by express, 2-yr. 40c., $\star$-size $60 \mathrm{c}$

Rosa Rugosa Magnifica. (H.R.) Fls. brilliant carmine, large, double, insects; attractive aside from the flowers. Vigorous. Bush, garden, or hedge. Prune 6, $7+$. (See cut, p. 2I.)

I-yr. 75c., postpaid; by express, 2-yr. \$1.25, $\star$-size \$2.

RUBY QUEEN. (H.C.) Fls. ruby, with white center; large, double, in clusters. Vigorous. Pergolas, pillars, etc. Prune $6,7+$.

I-yr. I5c., postpaid; by express, 2-yr. 30c., $\star$-size $50 c$.

SAFRANO. (T.) Fls. apricot-yellow, fragrant, semi-double; constant bloomer. Vigorous. Bedding, garden, edging and pot. Good button-hole Rose; an old favorite, never superseded. Prune 3. (See cut, p. 22.)

I-yr. Ioc., postpaid; by ezpress, 2 -yr. 30c., $\star$-size $60 c$.

SCHNEEKOPF. (P.) Fls. waxy white, sometimes tinted pink, petals cup-shaped; free bloomer. Vigorous. Bush. Prune 2.

I-yr, 20c., postpaid; by express, 2-yr. 40c., $\star$-size $60 c$

Sir Thomas Lipton (H.R.) Fls. pure white, fragrant; constant bloomer. Lvs. beautiful. Vigorous. Hedge bush or garden. Prune $5,7+$. Very hardy.

r-yr. 25c., postpaid; by express, 2-yr. 50c., $\star$-size $\$$ r.

SOMBRIEUL. (T.) Fls. creamy white, tinged rose; very large, full and sweet, and remains in open perfection many days. Bedding. Prune 3 .

I-yr. Ioc., postpaid; by express, 2 -yr. 30c., $\star$-size $60 \mathrm{c}$

SOUVENIR DE PIERRE NOTTING. (T.) Fls. orange-yellow, shaded rose, large, full, double; a most pleasing color combination. Vigorous. Garden, bedding. Prune 3. Has received six gold medals and grand prizes.

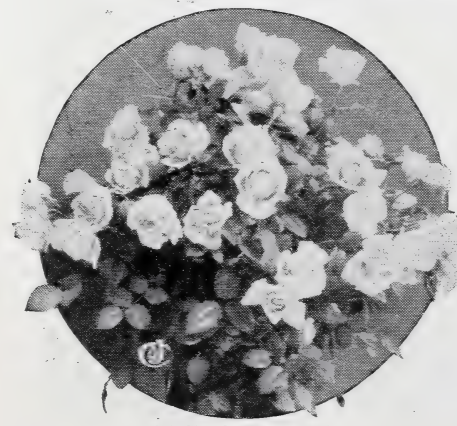

Wellesley (p. 24) I-yr. 20c., postpaid; by express, 2-yr. 40c., $\star$-size $60 \mathrm{c}$.

SOUVENIR DU PRES. CARNOT. (H.T.) Fls. shell - pink, large, full, deep, fragrant. An extraordinary Rose in its color and general vigor. Vigorous Bedding, garden, pot. Prune 2. I-yr. I5c., postpaid; by express, 2-yr. 35c., $\star$-size $60 \mathrm{c}$.

SOUV. OF WOOTTON. (H.T.) Fls, rich velvety red; equal to General Jacqueminot in color; profuse bloomer, very sweet. Especially desirable for its admired crimson color. Bedding. Prune 2. I-yr. I5C., postpaid; by express, 2-yr. 35c., $\star$-size $60 \mathrm{c}$

FOR EASY SELECTION, see special sets on pages 25 to 33

23 See Explanatory Key on pages 11 and 12 


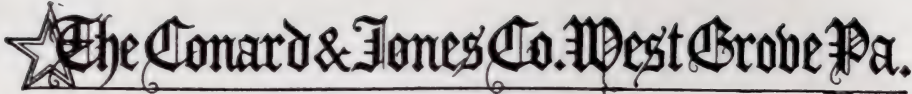

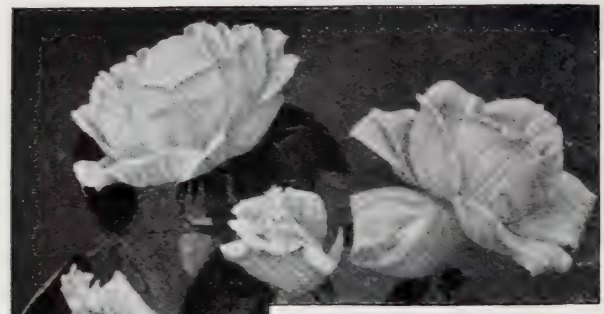

SWEET BRIER (R. rubiginosa). (H.C.) Fls. pink. Single. Vigorous. Hedges, bush. Prune $6,7+$. Valued for delightful fragrance of its foliage. By express, 2-yr. $40 \mathrm{c}$.

TAUSENDSCHON.(H.C.) Fls. white to deep pink. Very vigorous.Porches, arches, etc. Prune 6, $7-$. Has few thorns. One of the best of the recent introductions. I-yr. 20c., postpaid; by express, 2-yr. 30c., $\star$-size $75 \mathrm{c}$.

Ulrich Brunner. (H.P.) Fls. rich red, fragrant; Vigorous. Garden, bedding and standard. Prune I for $\mathbf{x}, 3$ for s. A very desirable variety. (See cut.) I-yr. I5c., postpaid; by express, 2 -yr. 35c., $\star$-size $60 \mathrm{c}$.

(6)

UNIVERSAL FAVORITE. (H.W.) Fls clear pink, double. Vigorous. Creeping. Prune 6, $7-$. A charming companion for the double White Memorial Rose I-yr. I5c., postpaid; by express, 2-yr. 35 c., $\star$-size $50 c$.

Vick's Caprice

VICK'S CAPRICE. (H.P.) Fls. pink, striped white; very double. Vigorous Bedding. Prune 2 for $x, 3$ for $s$. An attractive Rose, out of the ordinary and very popular. (See cut.)

I-yr. 20c., postpaid; by express, 2-yr. 40c., $\star$-size $60 \mathrm{c}$

Wellesley, (H.T.) Fls. rose-pink on tall, stiff stems; free bloomer. Vigorous. Bedding, pot. Prune 2. (See cut, p. 23.)

I-yr. 20c., postpaid; by express, 2-yr. 40c., $\star$-size 6oc.

WhITE MAMAN COCHET. (T.) Fls. pure white, large, full, fragrant. Buds long, pointed. Vigorous. Garden, bush. Prune 2.

I-yr. I5c., postpaid; by express, 2-yr. 35c., $\downarrow$-size $60 c$.

WICHURAIANA. (W.) Fls. pure white, single. Lvs. glossy, free from insects. Vigozous. Creeping. Prune 6, $7-$. Will grow anywhere.

I-yr. I5c., postpaid; by express, 2-yr. 35c.

WILLIAM ALLEN RICHARDSON. (C.T.) Fls. coppery yellow, tinged carmine; large, full, fragrant. Vigorous. Unique for its rich color. Porches, pergolas. Prune 3 for $x, 5$ for s. Hardy only in the South.

I-yr. Ioc., postpaid; by express, 2-yr. 30c., $\star$-size $60 c$.

WINNIE DAVIS. (H.T.) Fls. apricot-pink, shading to flesh tint at che base of petals; buds are long, heavy and splendidly formed. Bedding. Prune 2. I-yr. I5c., postpaid; by express, 2-yr. 35c., $\star$-size 6 oc.

W. R. SMITH (Jeannette Heller). (H.T.) Blushpink, large, full. Vigorous grower. Prune I for $x, 3$ for s. Has the fine qualities of the famous Maman Cochet and is even more vigorous. I-yr. $25 \mathrm{c}$., postpaid; by express, 2-yr. 5oc., $\star$-size $75 \mathrm{c}$.

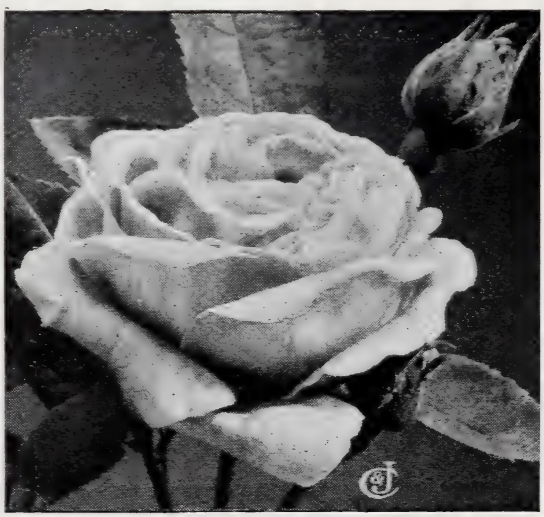

Ulrich Brunner

FOR EASY SELECTION, see special sets on pages 25 to 33

See Explanatory Key on pages 11 and 1224 


\section{The 2Best Groses in America th}

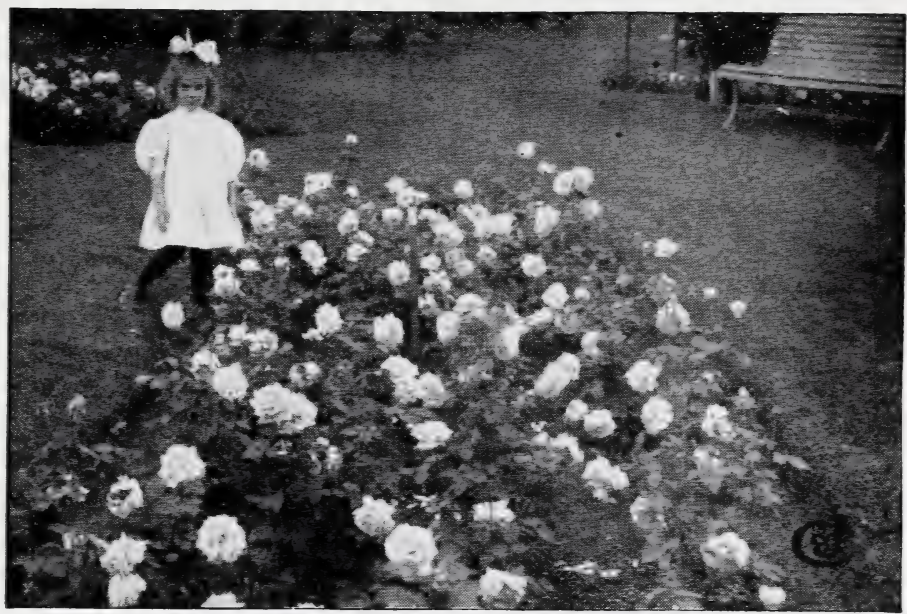

Mme. Camille. Beautiful on the lawn; just as fine in vases

\section{Twelve "Best-Yet" $\star$ Roses}

SELECTED FROM OVER I,000 KINDS. (READ HOW)

In selecting the best Roses, there are so many qualities to be considered that it requires a large collection and unusual opportunities to watch and study them under every possible condition they are likely to encounter. We have been fortunate in having unusual facilities for this experimental work. To pass our severe test a Rose must prove itself a vigorous grower and abundant bloomer, in addition to other excellent qualities of size, form, color, fragrance, etc.

The Roses in this set we know as we know the members of our family, and we commend them as kinds you can depend upon to respond generously to proper care in whatever Rose-growing locality you live.

In buying this "Best-Yet" set, you avoid experimenting, for which we have paid, and have at hand sorts which will give you a glory of good bloom if you supply a little decent attention.

Frau Karl Druschki (H.P.).... White I Beauty of Rosemawr (B.).... Pink Kaiserin AugustaVictoria (H.T.) White La France (H.T.)............ Pink

White Maman Cochet (T.) .... White Gen. Jacqueminot (H.P.) .....Red Mrs. John Laing (H.P.).........Pink Prince Camille de Rohan (H.P.). Red Paul Neyron (H.P.) ..........Pink Gruss an Teplitz (H. T.)....... Red Bessie Brown (H.T.).........Pink Mme. Eugene Marlitt (B.) ....Red FOR DESCRIPTIONS AND PRICES SEE PAGES I3 to 24

OFFER NO. 701. THE ENTIRE SET FOR ONLY

\section{$\$ 1.25$ \\ in 1 -year size postPAID}

$\$ 3.50$ in 2 -year size by express collect or $\$ 4.00$ express PAID
$\$ 6.00$ in $3-$ year size by express collect or $\$ 6.75$ express PAID 


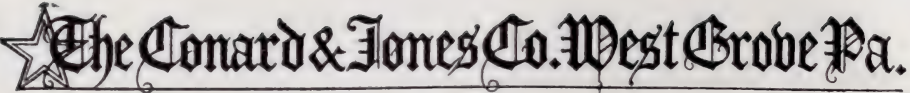

\section{"Best-Yet" Sunny South Set}

If you live on the sunny side of the frost line and wish a set of superior sorts for a warm country, here are I2 that we know you will find supremely satisfying.

These are our favorite $\mathrm{I} 2$ in a climate where there is little danger from frost. They will winter well as far north as Washington.
YELLOW-
PAGE
PINK -
PAGE
Etoile de Lyon (H.T.) ......... I 5
Countess of Gosford (H.T.)..... I 5
Mlle Helena Gambier ( $H$ T. ....22

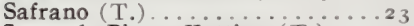
Souv. de Pierre Notting (T.) ...23
WHITE (tinted) -
Marie Van Houtte (T.)........2 I
Maman Cochet ( T.)............ I
Mme. Camille ( T.) ..........20
Mme. Caroline Testout (H.T.) ..20
Winnie Davis (H.T.) ........24 RED -
Mrs. B. R. Cant (T.) .........22
Magnafrano (H.T.)............ I
OFFER No. $\} \$ 1.25$ in 1 -year
702
size postPAID
\begin{tabular}{l|l}
$\$ 3.00$ in 2 -year & $\$ 5.00$ in 3 -year \\
size by express & size by express
\end{tabular}

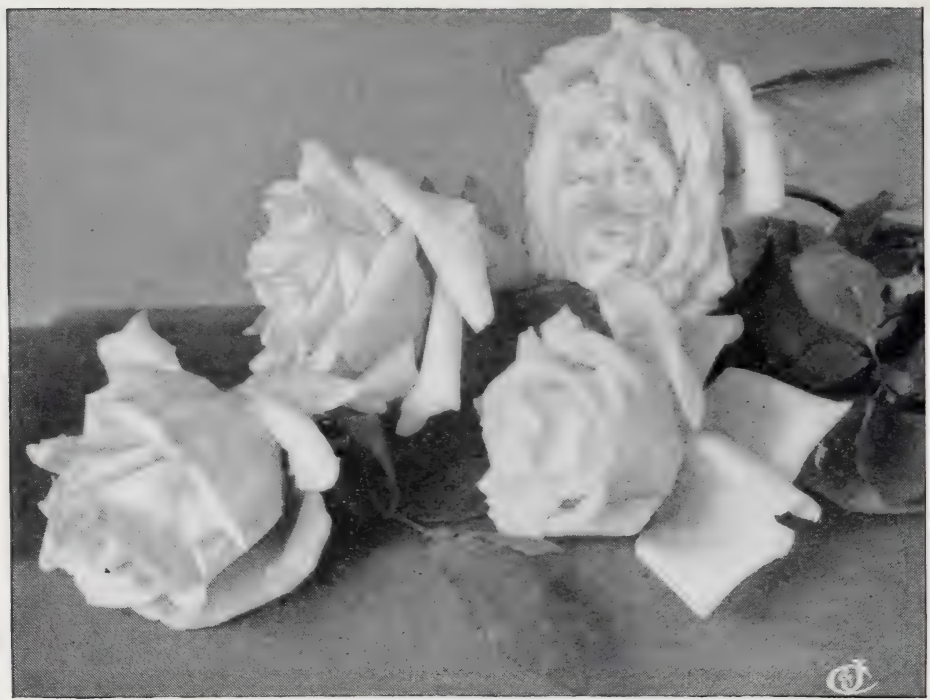

Think of gathering flowers like these almost every morning

\section{"Best Yet" Cold Country Set}

Here are Roses selected from among those that thrive and live outdoors over winter in localities north of the latitude of New York and Chicago. These laugh at zero weather.

Frau Karl Druschki (H.P.) . . . . I 5

Mme. Plantier (H.Cl.).........20

Sir Thomas Lipton (H.R.) $\ldots \ldots 23$

Conrad F. Meyer (H.D.) ....... I4

Comtesse de Murainais (M.) .... I4

PINK-

Sweet Briar (Rubiginosa)......24

Pink, continued PAGE Magna Charta (H.P.) ........... I

Princess Adelaide (M.) ........23

Anna de Diesbach (H.P.)....... I 3 RED -

R. rugosa magnifica (H.R.) . . .23 Baron de Bonstetten (H.P.) ....I4

Ulrich Brunner (H.P.) ........24

OFFER NO. 703

1-year, \$1.75, |2-year, \$3.50 express, or $\mid$ 3-year, $\$ 6.00$ express, or postPAID $\quad$ express PAID, \$4.00 


\section{The 25egt Groses in America - ts}

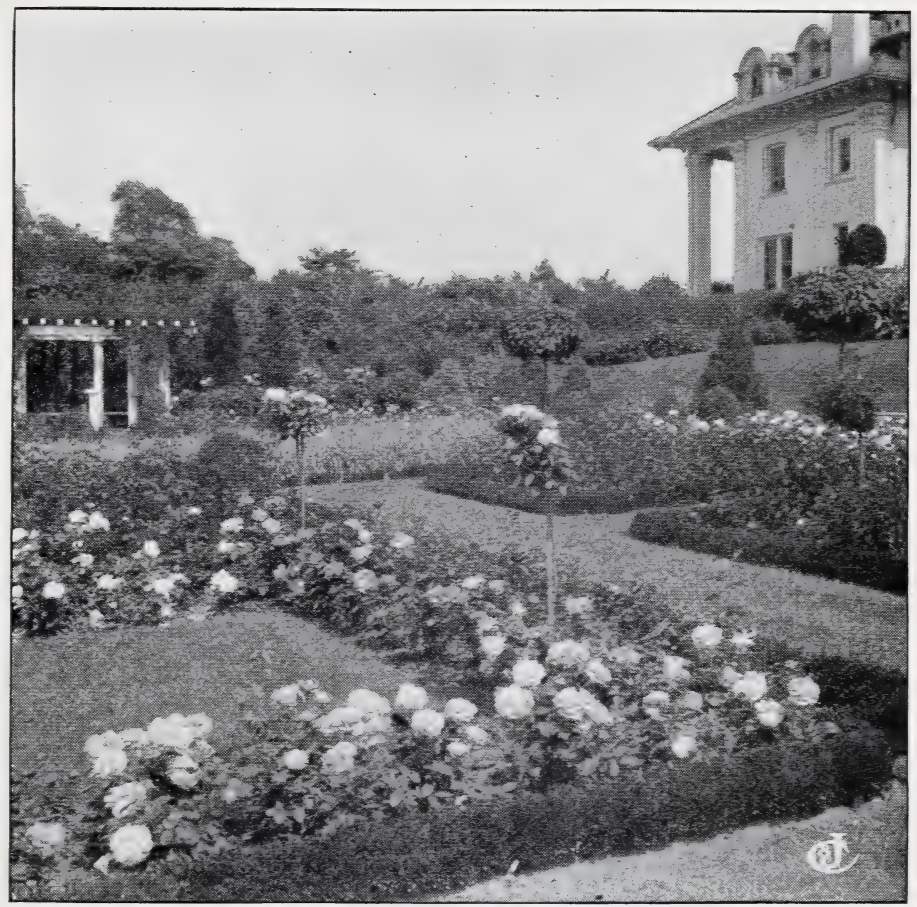

Nearly every house may have a dozen bushes like these

\section{"Best-Yet" New Roses for Igro}

The Blue Rose is a new Rose and we can supply it-but we do not consider it up to the standard of our "Ior."

The same thing might be said of other new ones, which for the same reason are not offered here.

But the kinds we do offer have won their way into this book only after the most severe tests, and it is a source of sincere pleasure that among the new Roses from European and American introducers there are so many that we can recommend. These are mainly Teas and Hybrid Teas, which, with protection, will prove hardy in the latitude of Philadelphia and in season repay your good care with prize blooms of surpassing loveliness.

We price them separately so you can try a few, if you have not room for all. (See desci iptions on pages $I_{3}$ to 24.)

PINKFlorence Pemberton. 2-yr... So $40 \quad$ Mme. Jules Gravereaux. 2-yr. \$o 35 Wm. R. Smith. 2-yr...... 50 SALMON PINK-

Cherry Ripe. 2-yr.......... 40

Dean Hole. 2-yr. 2-yr... $40 \quad$ Freiherr Von Marschall. 2-yr. 40

Lyon. 2 -yr. .............. I 00

OFFER NO. 704. ENTIRE SET OF NINE FOR ONLY (Omitting Lyon) in 1-year $\$ 3.75$ in 2 -year $\$ 6.00$ in 3-year size size $\$ 1.35$ postPAID size by express by express 


\section{For "Forcing" Under Glass or for Indoor Winter Bloom}

These varieties are used by professional florists in glass houses where they can with nicety regulate the supply of heat and moisture, etc., to produce the long-stemmed "beauties" seen in florists' windows. While a greenho e or conservatory is a wonderful help, it is not essential, for some people have these same Roses during the winter, to bloom beautifully in their homes: American Beauty (p. I3), Killarney (p. I7), Kaiserin Augusta Victoria (p. I 7), Magnafrano (p. 21), Gen'l. Jacqueminot (p. I6), Wellesley (p. 24). These 62 -yr., $\$ 2$ by express.

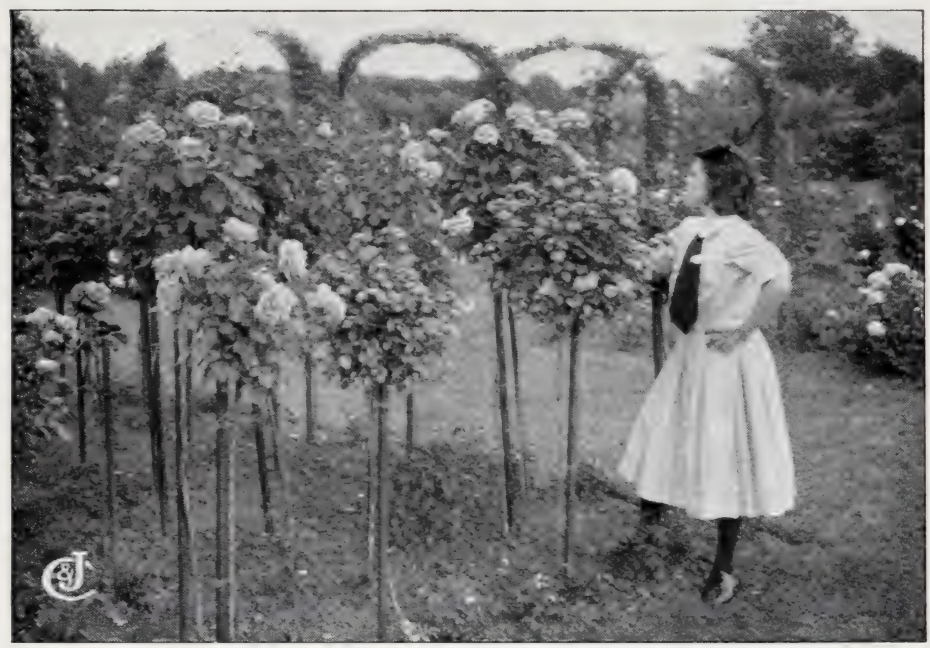

The Standard, or "Tree" Roses-so popular in English Gardens

\section{Standard or Tree Roses}

Tree Roses occupy but little ground space and are very imposing when planted among shrubbery or perennials. Along the sides of a walk they form an avenue effect. They can also be planted among or back of a collection of bush Roses-thus making a two-storied Rose-bed, as it were.

All the winter protection required is to loosen the soil at the roots enough to lean the plant so that the top comes near the ground, then it can be covered with soil or two boards nailed together V-shaped and filled with dry leaves. In the spring the weak shoots should be cut out and the stronger ones pruned back to three or four eyes. Order before April I. Frau Karl Druschki. (H.P.) Snow-

General Jacqueminot. (H.P.) Best red. Mrs. John Laing. (H.P.) Clear pink. Paul Neyron. (H.P.) Immense, rich pink.

UlrichBrunner. (H.P.) Crimson-scarlet.

Gruss an Teplitz. (H.T.) Often called the "reddest of red Roses;" fragrant and free-blooming.

Mad. Caroline Testout. (H.T.) Clear cherry-red.

Baby Rambler. (P.) The famous new crimson Rose.

\$1 each, \$9 per doz., by express only

OFFER No. 705-The entire set of EIGHT for \$6, by express only 


\section{The 2Begt Groses in America-}

\section{CLIMBING ROSES THAT WILL COVER}

\section{A TRELLIS QUICKLY}

UP PORCHES, OVER BUILDINGS, ETC.

Every home has room for a few climbers, because vines around a home decorate it as does nothing else, and to have vines that will hand you forth Roses-imagine the pleasure of that!

Where you live makes a difference; Roses that will grow to cover your house with bloom in North New England are not the kinds to do the same in the sunny South. - So, think of these things when you order-or, better still, leave it all to us and we will select to suit your home and climate. For example, here are three sets, each one is good for the section indicated-order accordingly and you'll get pleasing results.

*The first 2 in the mild climate set are quite hardy; the last 2 well-known beauties of the South may be grown as far north as Philadelphia, if given a southern exposure and ample winter protection.

\section{FOR A MILD CLIMATE \\ "EVERBLOOMING CLIMBERS"}

Empress of China. Pink .................

Mrs. Robert Peary Pink.......... I5

* Marechal Niel. Yellow...........

*Wm. Allen Richardson. Copper....24

OFFER NO. 706

Postpaid, the 4 in 1 -yr. size, 60c.

By express, the 4 in $2-y r$. size, $\$ 1.25$

By express, the 4 in 3 -yr. size, $\$ 2.25$

\section{FOR TEMPERATE CLIMATE}

LATITUDE OF N. Y. AND PHILA., PA.

Philadelphia Rambler. Red ...... PAGE Dorothy Perkins. Pink............... ${ }_{5}$

Empress of China. Pink ............ I5

Mrs. Robert Peary. White..........

OFFER NO. 707

Postpaid, the 4 in $1-y r$. size, $60 \mathrm{c}$.

By express, the 4 in $2-y r$. size, $\$ 1.25$

By express, the 4 in 3 -yr. size, $\$ 2.25$

\section{FOR A COLD CLIMATE}

Dorothy Perkins. Pink..... PAGE $\ldots$ I 5 American Pillar (Single). ......... I5 American Pillar (Single). Rosy pink ... $I_{3}$ Ruby Queen. Rosy Red............23 OFFER NO. 708

Postpaid, the 4 in 1-yr. size, 60c. By express, the 4 in 2 -yr. size, $\$ 1.25$ By express, the 4 in 3 -yr. size, $\$ 2.25$

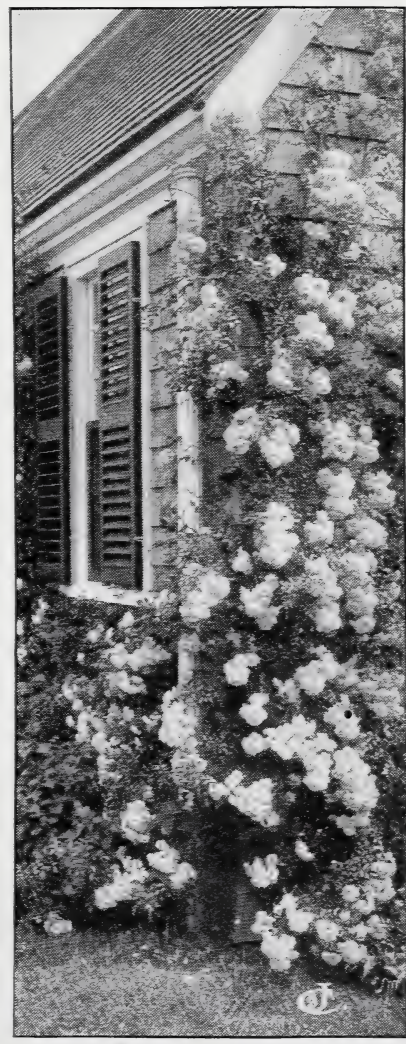

A home in New England made beautiful with Dorothy Perkins

My Roses are so beautiful and bloom so freely that they are much admired, and some of my friends have asked for my Catalogue. All of my Roses are from your house and I must tell you how glorious they are, and assure you it will be a pleasure to place all my orders with you. Mrs. G. A-, El Campo, Texas. 


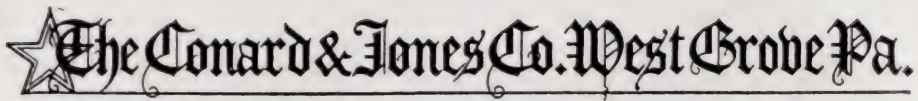

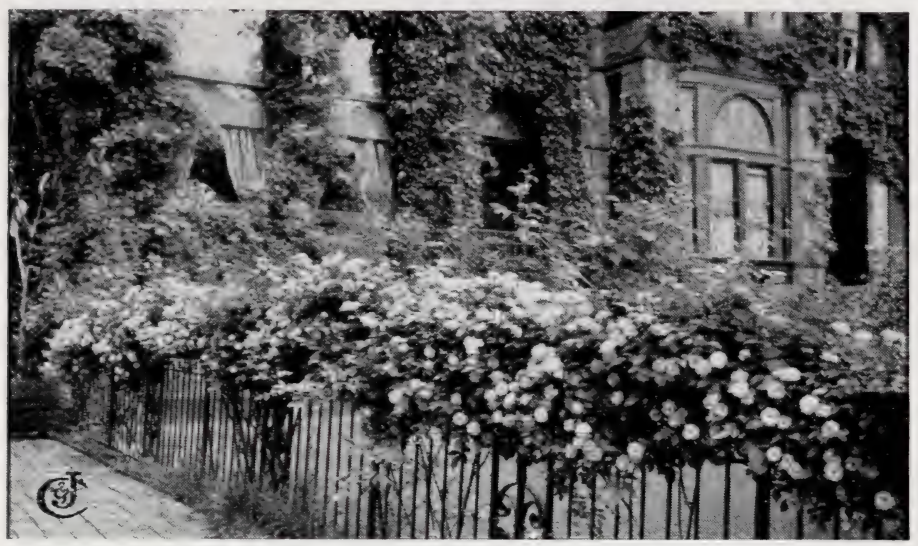

Ruby Queen crowns the fence with beauty

FOR BEAUTIFYING BOUNDARIES, FENCES, ETC.

Certain Roses lend themselves admirably to being trained over objects on which they can have support. The above illustration shows Ruby Queen draped over a fence; the best kinds for such a purpose, we think, are

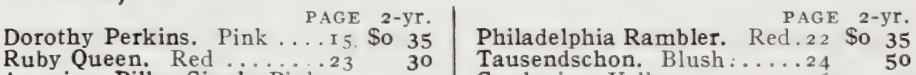

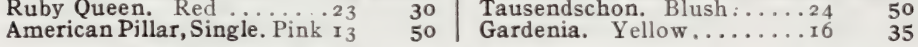

Quite as pretty an effect may be had with certain other kinds by allowing them to grow over a wall, as shown below. Their willowy vine-like branches are very graceful, the foliage is shiny and almost evergreen, giving these the advantage over the Ramblers of being attractive even when not in bloom and almost the entire year.

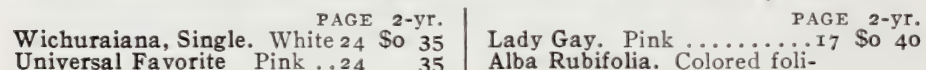

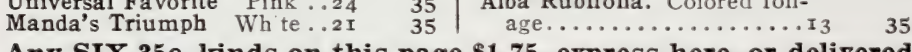

for $\$ 2$. For the above effect, plant from 3 to 8 feet apart

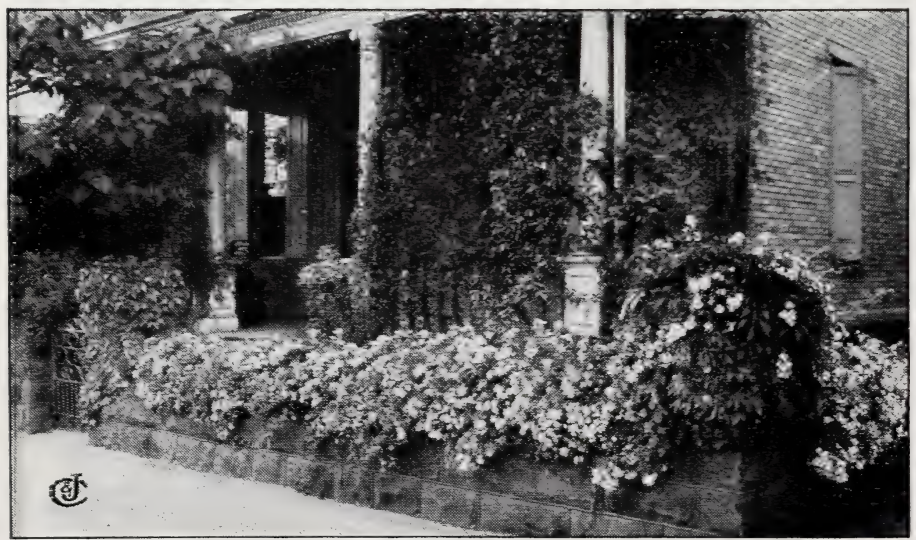

A wall made beautiful by Manda's Triumph 


\section{The 2best thoses in America}

\section{A ROSE HEDGE}

The best varieties for this purpose will depend upon where you live. For cold climates it is doubtful if you can get anything else quite so good as the Rugosa Roses, especially Sir Thomas Lipton, see page 23. Erect, stout, clean and healthy looking, with beautiful seed hips in the fall. Next comes the Sweet Briar (see page 24) with its deliciously fragrant foliage. This makes quite a dense growth under favorable conditions. But for both the above a more satisfactory result can be obtained by planting a post and wire fence to which the heavy upright canes can be fastened, somewhat as you would grapevines. A perfect glory of bloom and foliage will decorate that obliterated fence.

In warmer countries, or even in our own latitude, a single row of a free-flowering erect bushy Rose is sure to be pretty and very satisfactory where one wishes to simply mark a boundary, as, for example, between the vegetable- and flower-garden. For this purpose, Clotilde Soupert, see page I4, is excellent. In a different way the Polyanthas are also popular, especially Baby Rambler, see page I3, and Cecile Brunner, see page I4. and Baby Dorothy, see page I3. The list could readily be extended, and each one be well worth planting.

\section{FOR BORDER BEDS}

\section{ALONG A PATHWAY OR DRIVE}

The housekeeper knows how splendid it is to have plenty of flowers in bloom, so that she can run out and cut a bouquet when she needs them Here are nine good kinds for that purpose. A bed or border row all of one kind should bloom much as

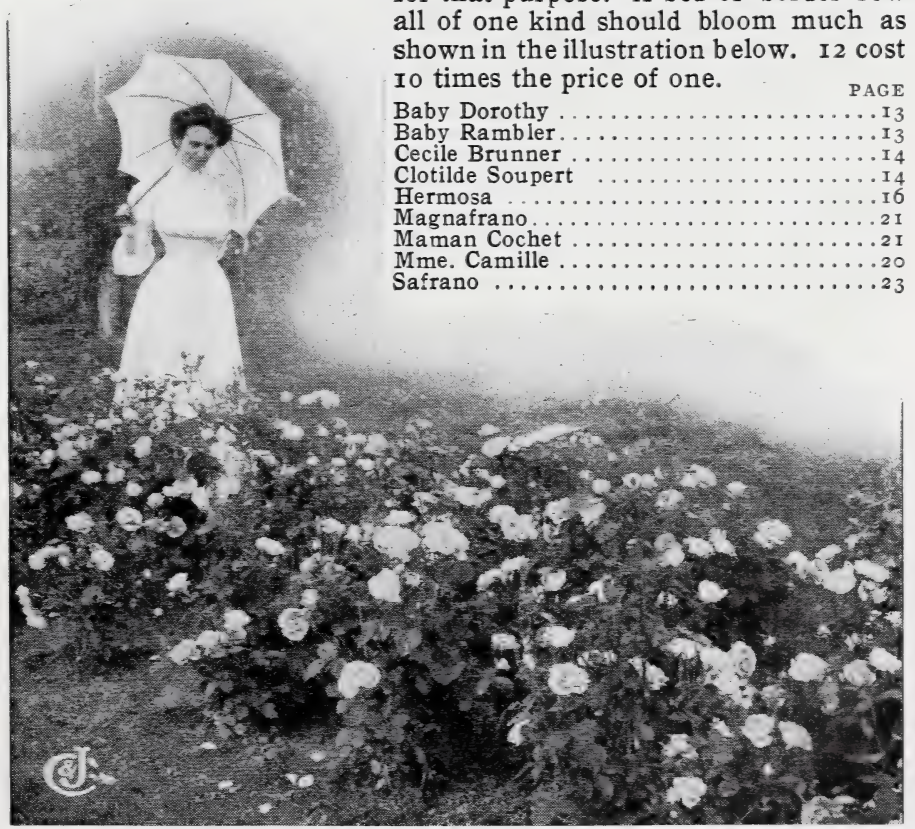

Twenty-four Magna Charta Roses will give an effect like this 


\section{She Comarde Iones Co. Dest CGrobe \#a.}

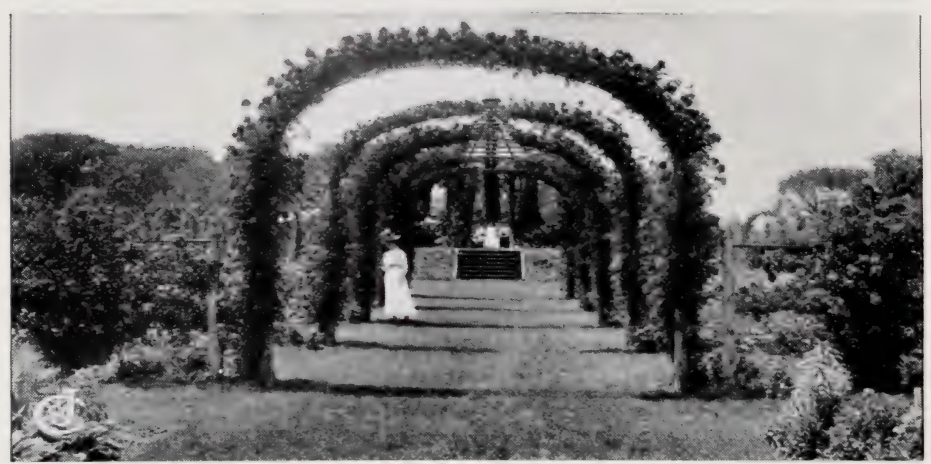

Triumphal Arches of Rambler Roses

\section{Archways, Arbors, Summer-Houses, Pergolas}

This picture tells its own story. Each archway requires only two Roses well planted in rich soil, and 2-year's growth will "do the rest." Of course, they will need a little training and tying.

These same varieties are the best kinds to cover summer-houses, arbors, bowers and pergolas. Whatever you build by way of support, make it substantial. If properly nourished and trained, these Roses will soon grow to hide such frame-work and be a beautiful addition to your grounds.

Philadelphia Rambler. Red (p. 22) ............ So 20 \$o 35 \$o 85

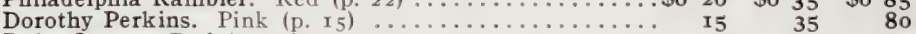

Ruby Queen. $\operatorname{Red}(\mathrm{p}, 23) \ldots \ldots \ldots \ldots \ldots \ldots \ldots \ldots \ldots$ ro $30 . \ldots \ldots$

Wichuraiana (Single). Pink (p. 24)................. $15 \quad 35$ 6о

OFFER NO. 709-The 4, 1-yr. size, 50 cts. prepaid; the 4, 2-yr. size, $\$ 1.10$ by express; the $4,3-y r$. size, $\$ 2.50$ by express

\section{OTHER GOOD ONES FOR ABOVE PURPOSE}

Any of the Wichuraianas, also Empress of China (p. I5), Lady Gay (p. I7), Crimson Rambler (p. I5), Queen Alexandra (p. 23), Tausendschon (p. 24), Mrs. Robert Peary (p. 22), Marechal Niel (p. 2I) and Wm. Allen Richardson (p. 24), the last two for the South only.

One dozen of any of the above for ten times the price of one

Any handy man can erect an archway. It should be very substantial, and should have locust or cypress posts for permanence.

We can also tell you wher e to get and the right price to pay for ready-made metal archways, if you write us.

\section{For Screen Planting and Borders}

Almost every lawn might be improved if some uncomely object or portion in the rear were screened from view. The right kind of Roses will do it, and give you something beautiful instead. There are two ways to do it: (I) Put up a trellis and train over it the Roses offered in the first group on the opposite page, or (2) if it be only a low screen you need plant the tall erect-growing Rugosa Roses. (And if you want a luxuriant growth dig the ground deeply and give these Roses plenty of rich nourishment.)

Conrad F. Meyer. Silvery pink. 2-yr. $\$$

OFFER NO. 710

Alice Aldrich. Pink

Rosa rugosa magnifica. Carmine .. I 25 2-yr. size, $\$ 2.50$ by express; Sir Thomas Lipton. White ........ 50 3-yr. size, $\$ 3.75$ by express.

These four if in one group should be set 2 to 3 feet apart. 


\section{The 20est Hoses in America-}

\section{ROSES FOR THE CEMETERY}

For some cemeteries we recommend Roses that almost care for themselves-the Wichuraiana type. They creep like ivy and make a mat of shiny foliage which is green for eleven months.

If you can care for Bush Roses, select from the "Best-Yet" sets, according to locality - but if you want some of the sturdiest Bush Roses obtainable choose from this list-all white but one.

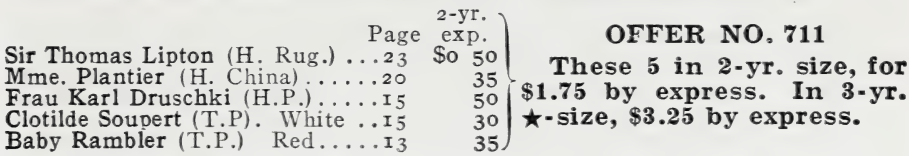

You may select a 50c. and a $35 \mathrm{c}$. kind for $75 \mathrm{c}$. by express

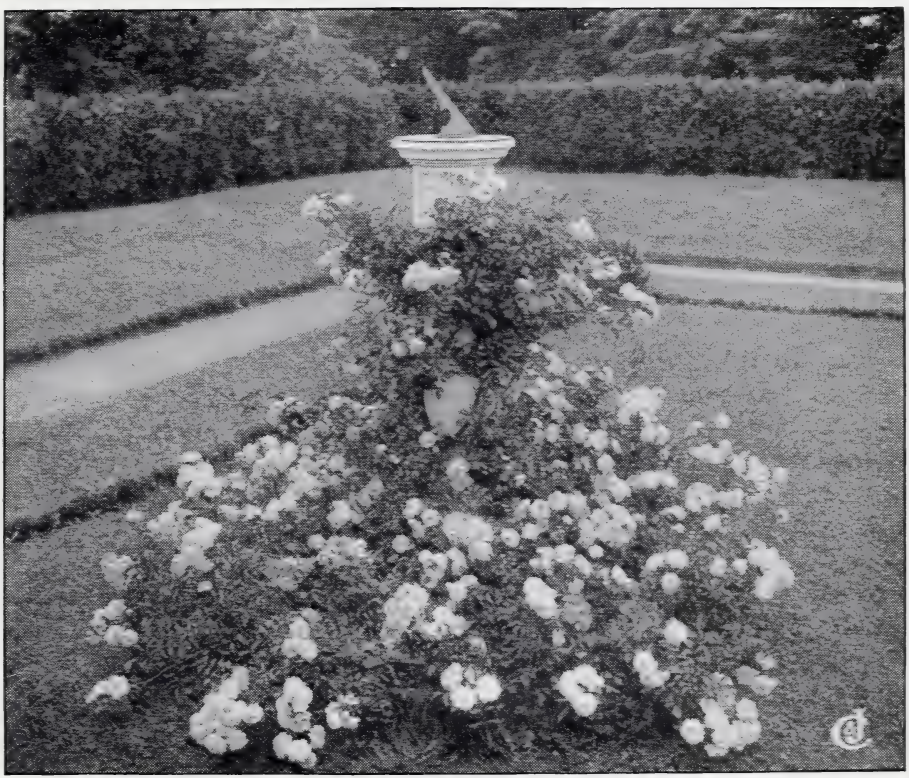

Dorothy Perkins round a Sundial which "marks the sunny hours"

\section{FOR COVERING A BANK}

OR STUMPS OR LIKE OBJECTS

The Wichuraianas (shown in the above illustration) are ideal cover Roses. They are remarkably free from both insects and disease and look clean and fresh the entire year.

The single-flowered sorts bear bright berries, which the birds like. Railroad companies use these to hold embankments in place; they also add to the roadside beauty.

Alba Rubifolia. Beautiful shiny foliage ${ }^{2}$ Prepaid Exp. Exp. Gardenia (Hardy Marechal Niel) (p. I6)....... each \$o $1_{5}$ \$o 35 So 50 Manda's Triumph. White, very fragrant $(\overrightarrow{\mathrm{p}} .2 \mathrm{I}) .$.$\} doz. I 50 \quad 300 \quad 450$ Universal Favorite. Double Pink Memorial (p. 24) 100 10 $00 \quad 2200 \quad 3500$ Wichuraiana (Single). White (p. 24$) \ldots \ldots \ldots \ldots$.......
One plant will easily cover 6 square feet of ground 


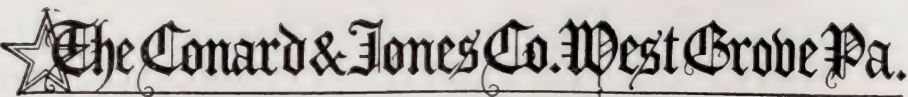

\section{THE ROSE LOVER'S CALENDAR}

These dates are for the latitude of Philadelphia. It is a good rule to allow four days' difference for every one hundred miles of latitude.

MARCH I5.-Prune Hardy Roses.

MARCH 25-30.-Plant Hardy Roses that may be had dormant. These should be well cut back.

APRIL I-I5.-Prune tender Roses. Begin to remove protection as the weather moderates, and fork in the manure that has been lying on the ground since Fall.

APRIL 20-25.-Finish uncovering your Roses, plant new ones, and spray all your Roses with Rose Nicotine or Kerosene Emulsion.

MAY Io.-Spray for Insects as per directions unfer "Enemies."

MAY 20.- Spray again if necessary. Weak manure water applied now will make finer flowers later.

MAY 25.-Rugosas and Yellow Briers begin blooming.

JUNE I.- "Feast of Roses" begins.

JUNE I. - The Hybrid Perpetuals soon begin blooming.

JUNE I -7.-Watch for the Rose Beetle and Rose Slug, and spray every ten days with arsenate of lead (I lb. to Io gals. of water); apply liquid manure to Teas and Hybrid Teas.

JUNE 20 to July I. - Now the Hybrid Teas and Teas and Climbers should be blooming in abundance.

Look out for mildew and apply grape-dust. Keep the soil well hoed.

JULY I0.- Keep the Roses cut off so as not to let any die on the bushes. If the foliage shows signs of fungoid troubles, such as black spot, mildew or yellow leaves, apply weak Bordeaux mixture, fortnightly, till the last of August. If any Aphis, use Rose Nicotine.

JULY 20, or earlier.-Mulch your Roses with grass cuttings, old manure, or leaves.

AUGUST 30.- Teas and Hybrid Teas begin their fall display. Bon Arbor or manure water about the roots will help them do their best.

SEPTEMBER Io.-Some Kybrid Perpetuals bloom again.

OCTOBER I5.-Make ready new beds for next year.

NOVEMBER I5.- After the first frost, begin covering the tender Roses. Finish all to a proper depth when it freezes hard.

\section{INSECTICIDES}

THOMPSON'S ROSE NICOTINE is chemically pure nicotine and quick death to insects on Roses. No trouble, no odor, no staining; simply apply as directed with spray pump or plant sprinkler. Small can 3oc., larger size $65 \mathrm{c}$., postpaid; by express, $25 \mathrm{c}$. and $50 \mathrm{c}$.

SULPHO-TOBACCO SOAP. Another splendid insecticide. Directions for use on every package. Three oz. cake makes $I_{4}^{\frac{1}{4}}$ gallons prepared solution, roc. each; 8-oz. cake makes 5 gallons prepared solution, 25c., postpaid.

HELLEBORE, POWDERED WHITE. For the destruction of slugs, worms, caterpillars, etc. Less poisonous than Paris Green and London Purple, and safer to use. Use as a powder or dissolve one ounce in three gallons of water. $\frac{1}{2} 1 \mathrm{~b}$. box I5c., $20 \mathrm{c}$. per lb., $5 \mathrm{lbs}$. 9oc., Io lbs. $\$ 1.75$, 25 lbs. and over at I6c. per lb., by express; postpaid, $\frac{1}{2} 1 \mathrm{~b}$. $25 \mathrm{c}$., for other quantities add I6c. extra to express price for every pound.

GRAPE DUST. For mildew, mold or rust mites. Ioc. per 1b., 5 lbs, $35 \mathrm{c}$., by express only (not prepaid); postpaid, $25 \mathrm{c}$. per $1 \mathrm{~b}$, 


\section{COVER-PAGE ROSES}

\section{American Pillar}

A vigorous, strong, branching pillar Rose which, for over a month in the spring, fairly covers itself with heavily laden clusters of large, rich, rosy pink single flowers. One bush on our grounds, less than 4 feet high, had on it over 3,000 blossoms at one time last spring, and wherever shown it has elicited the most enthusiastic admiration and praise. It has tough deep green foliage, and red seed-hips in the fall. Entirely hardy. I-yr. size $25 \mathrm{c}$. each, larger size $35 \mathrm{c}$., postpaid: by express, 2-yr. size 50c., 3-yr. size \$r.

\section{White American Beauty}

\section{FRAU KARL DRUSCHKI}

Pure snow-white, with long buds and immense perfectly doubl $\rightarrow$ flowers (4 to 5 inches across), and very durable. It is quite the most continuous-flowering Rose in this excellent class. The bush is a vigorous grower with luxuriant foliage and perfectly hardy. Both for the garden and for bouquets, undoubtedly the finest white Rose in existence. I-yr. size 25 cts. each, I 2 for $\$ 2.50$, postpaid; by express, 2 . yr. size 50 cts. each, I 2 for $\$ 5$; Star size (3-yr.) \$I each.

\section{WHEN YOU ORDER}

The enclosed Order Sheet and Envelope will be found a conveniencemore will be sent on request

Order Early.- - It pays in many ways.

State the Date upon which you wish the order sent, so we can reserve for you the early pick of things and have all ready to ship at the right time.

Money should accompany the order, and may be sent at our risk if forwarded by Postal or Express Money Order, Bank Draft or in Registered Letter.

Foreign Orders.--To cover additional cost of packing, etc., customers living outside U. S. A. will add 20 per cent extra payments to amounts named in this book.

Our Spanish Catalogue of Roses will be sent on request.

Prices and Discounts.-Each Rose is priced separately in three sizes (see under descriptions),

On items bought at single rates deduct i5 per cent discount on all orders over $\$ 2$ and less than $\$ 5$.

On items bought at single rates deduct 20 per cent discount on orders of $\$ 5$ or more. No discount from the following, i. e., prices of sets are net. The net price per dozen of any Rose is 10 times the price per single plant. The net price per 100 is 75 times the price per plant. No further discount from these net prices.

Cost of Express. - The 1-year size Roses will be sent, postpaid, at prices named. 2- and 3-year size Roses go best by Express. If you wish us to prepay the express charges on orders for six or more plants, add 50 ets. per doz., or 5 cts. extra to the cost of each plant. If less than six plants are ordered to come at one time, add $10 \mathrm{cts}$. extra to the cost of each plant.

Our 136-page Catalog, offering nearly 500 Roses, also a select assortment of Shrubbery, Hardy Perennials, House Plants, Seeds, Bulbs, Cannas and Lilies, will be sent free on request.

We shall be glad to correspond with any one contemplating a Rosegarden. We design and furnish them complete. We are Rose specialists.

\section{THE CONARD \& JONES CO., West Grove, $\mathrm{Pa}$.}

d. Horace mcFarlano company, Mt. Pleasant Press, haprisburg, Pa. 

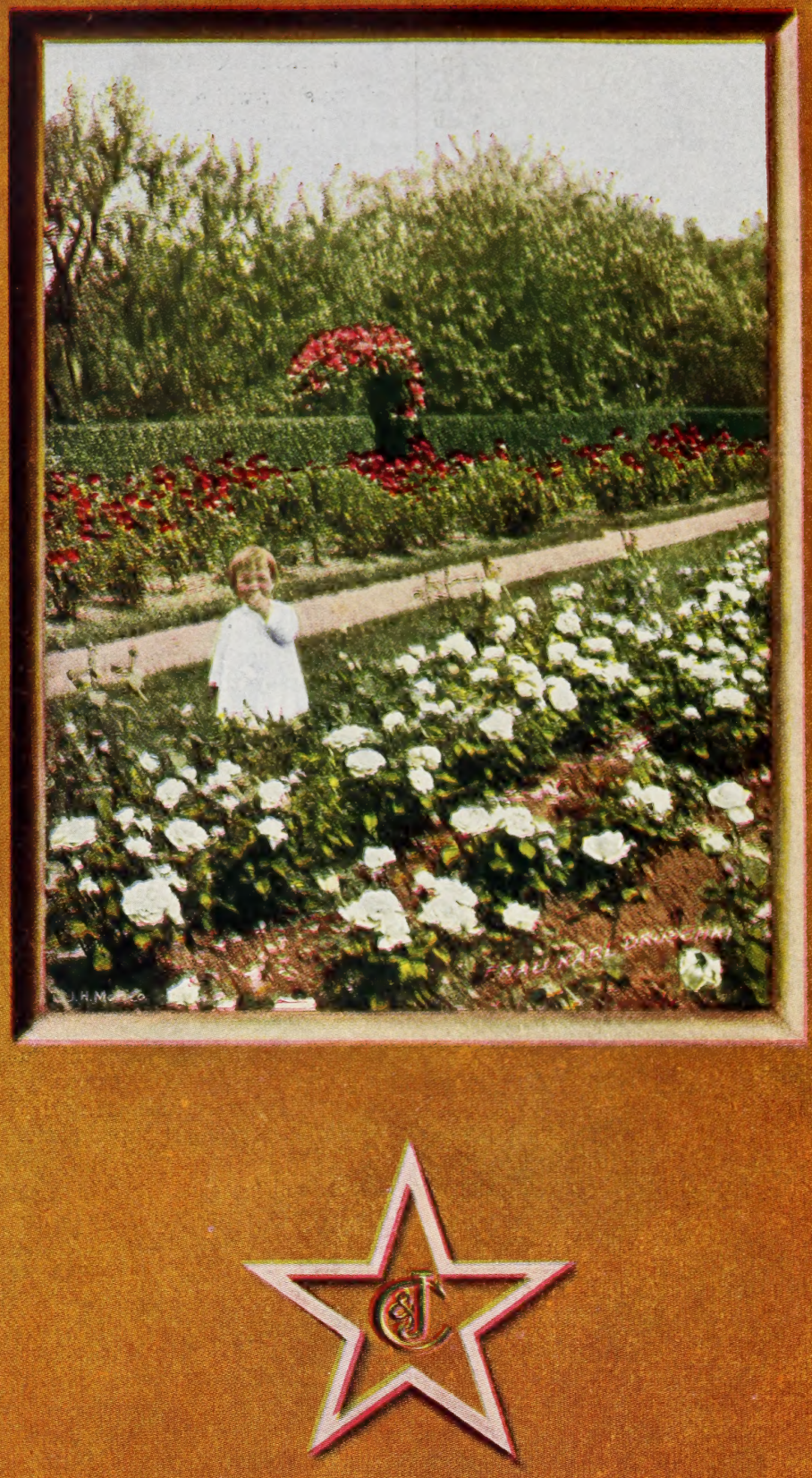

